\title{
Pericarditis and myocarditis long after SARS-CoV-2 infection: a cross-sectional descriptive study in health-care workers
}

Rocio Eiros, $\mathrm{MD}^{1}$; Manuel Barreiro-Perez, MD, $\mathrm{PhD}^{1}$; Ana Martin-Garcia, MD, $\mathrm{PhD}^{1}$; Julia Almeida, MD, $\mathrm{PhD}^{2}$; Eduardo Villacorta, $\mathrm{MD}, \mathrm{PhD}^{1}$; Alba Perez-Pons, $\mathrm{MScM}^{2}$; Soraya Merchan, $\mathrm{MD}^{1}$; Alba Torres-Valle, $\mathrm{MSc}^{2}$; Clara Sánchez Pablo, $\mathrm{Nr}^{1}$; David González-Calle, $\mathrm{MD}^{1}$; Oihane Perez-Escurza, MSc${ }^{2}$; Inés Toranzo, $\mathrm{MD}^{1}$; Elena Díaz-Pelaez, $\mathrm{MD}^{1}$; Blanca Fuentes-Herrero, $\mathrm{MSc}^{2}$; Laura Macías-Alvarez, $\mathrm{PhD}^{1}$; Guillermo Oliva-Ariza, MSc' ${ }^{2}$, Quentin Lecrevisse, Eng ${ }^{2}$; Rafael Fluxa, Eng ${ }^{2}$; Jose L Bravo-Grande, MD, $\mathrm{PhD}^{3}$; Alberto Orfao, MD, $\mathrm{PhD}^{* 2}$; Pedro L Sanchez, MD, $\mathrm{PhD}^{* 1}$

On behalf of the CCC ("Cardiac Covid-19 health Care workers") investigators (see in Supplementary Appendix)

*AO and PLS have contributed equally to this work and share last authorship

From the:

${ }^{1}$ Cardiology Department, University Hospital of Salamanca, IBSAL, Faculty of Medicine, University of Salamanca, and CIBERCV (ISCiii), Salamanca, SPAIN.

${ }^{2}$ Translational and Clinical Research Program, Centro de Investigación del Cáncer (CIC) Instituto de Biología Molecular y Celular del Cancer (IBMCC), CSIC-University of Salamanca, Cytometry Service, NUCLEUS, IBSAL, and CIBERONC, Salamanca. SPAIN.

${ }^{3}$ Occupational Health Service, University Hospital of Salamanca, IBSAL, Faculty of Medicine, University of Salamanca, Salamanca, SPAIN.

Address for Correspondence:

Pedro L Sanchez, MD, PhD

Department of Cardiology, Hospital Universitario de Salamanca

Paseo de San Vicente 58. 37007 Salamanca. SPAIN.

e-mail: pedrolsanchez@secardiologia.es

Telephone: 34-923-291100 extension 55356 
medRxiv preprint doi: https://doi.org/10.1101/2020.07.12.20151316; this version posted July 14, 2020. The copyright holder for this preprint

(which was not certified by peer review) is the author/funder, who has granted medRxiv a license to display the preprint in perpetuity.

It is made available under a CC-BY-NC-ND 4.0 International license .

\section{Pericarditis and myocarditis long after SARS-CoV-2 infection: a cross-sectional}

descriptive study in health-care workers

Eiros et al. 2

\section{Abstract}

\section{Background}

Cardiac sequelae of past SARS-CoV-2 infection are still poorly documented. We conducted a cross-sectional study in health-care workers to report evidence of pericarditis and myocarditis after SARS-CoV-2 infection.

\section{Methods}

We studied 139 health-care workers with confirmed past SARS-CoV-2 infection (103 diagnosed by RT-PCR and 36 by serology). Participants underwent clinical assessment, electrocardiography, laboratory tests including immune cell profiling and cardiac magnetic resonance (CMR). Pericarditis was diagnosed when classical criteria were present, and the diagnosis of myocarditis was based on the updated CMR Lake-Louise-Criteria.

\section{Results}

Median age was 52 years (IQR 41-57), 100 (72\%) were women, and 23 (16\%) were previously hospitalized for Covid-19 pneumonia. At examination (10.4 [9.3-11.0] weeks after infectionlike symptoms), all participants presented hemodynamic stability. Chest pain, dyspnoea or palpitations were observed in $58(42 \%)$ participants; electrocardiographic abnormalities in 69 (50\%); NT-pro-BNP was elevated in $11(8 \%)$; troponin in $1(1 \%)$; and CMR abnormalities in $104(75 \%)$. Isolated pericarditis was diagnosed in 4 (3\%) participants, myopericarditis in 15 $(11 \%)$ and isolated myocarditis in $36(26 \%)$. Participants diagnosed by RT-PCR were more likely to still present symptoms than participants diagnosed by serology (73 [71\%] vs 18 [50\%]; $\mathrm{p}=0.027)$; nonetheless, the prevalence of pericarditis or myocarditis was high in both groups (44 [43\%] vs 11 [31\%]; $\mathrm{p}=0.238)$. Most participants (101 [73\%]) showed altered immune cell counts in blood, particularly decreased eosinophil (37 [27\%]; $\mathrm{p}<0.001)$ and increased CD4CD8${ }^{1 / \mathrm{o}} \mathrm{T} \alpha \beta$-cell numbers (24 [17\%]; $\left.\mathrm{p}<0.001\right)$. Pericarditis was associated with elevated CD4CD8${ }^{/ 10} \mathrm{~T} \alpha \beta$-cell numbers $(\mathrm{p}=0.011)$, while participants diagnosed with myopericarditis or myocarditis had lower $(\mathrm{p}<0.05)$ plasmacytoid dendritic cell, NK-cell and plasma cell counts and lower anti-SARS-CoV-2-IgG antibody levels $(\mathrm{p}=0.027)$.

\section{Conclusions}

Pericarditis and myocarditis with clinical stability are frequent long after SARS-CoV-2 infection, even in presently asymptomatic subjects. These observations will probably apply to the general population infected and may indicate that cardiac sequelae might occur late in association with an altered (delayed) innate and adaptative immune response.

The trial is registered with ClinicalTrials.gov, number NCT04413071

\section{Keywords (MeSH terms)}

SARS-CoV-2; COVID-19; health-care worker; pericarditis; myocarditis; cardiac magnetic resonance; electrocardiogram; immune response; immune cells; serology 
medRxiv preprint doi: https://doi.org/10.1101/2020.07.12.20151316; this version posted July 14, 2020. The copyright holder for this preprint

(which was not certified by peer review) is the author/funder, who has granted medRxiv a license to display the preprint in perpetuity.

It is made available under a CC-BY-NC-ND 4.0 International license .

Pericarditis and myocarditis long after SARS-CoV-2 infection: a cross-sectional

descriptive study in health-care workers

Eiros et al. 3

\section{Research in context}

\section{Evidence before this study}

Very little evidence exists describing long cardiac sequelae after SARS-CoV-2 infection. Although pericarditis and myocarditis are the two most frequent cardiac manifestations observed after a viral infection, as of May 13, 2020, the peer-reviewed literature was limited to isolated case reports of myocarditis and pericarditis during the COVID-19 hospitalization phase and to a retrospective observation in 26 recovered patients with COVID19 pneumonia presenting cardiac complaints during hospitalization, revealing the presence of myocardial oedema in $14(54 \%)$ patients and late gadolinium enhancement in $8(31 \%)$ patients. These small size case series, limited to hospitalized RT-PCR patients with COVID-19 pneumonia, are insufficient to generalize conclusions about the true prevalence of pericardial and myocardial long involvement after SARS-CoV-2 infection. In addition, no study has investigated the immunological consequences of SARS-CoV-2 infection in the settings of pericarditis and myocarditis.

\section{Added value of this study}

To our knowledge, this is the largest cohort of subjects $(\mathrm{N}=139)$ - even for other common viruses - with clinical, electrocardiographic, laboratory and CMR imaging evaluations, to assess pericardial and myocardial involvements after SARS-CoV-2 infection. The strength of this study is the addition of non-hospitalized participants and also the inclusion of participants diagnosed of past SARS-CoV-2 infection through serology. Contrary to previous studies, women are well represented. We found a prevalence of pericarditis or myocarditis up to $40 \%$ cases; pericarditis coexisted with some degree of concurrent myocardial inflammation in $11 \%$ cases. Study participants who were previously hospitalized for COVID-19 pneumonia and patients who received antiviral (hydroxychloroquine, lopinavir-ritonavir) or anti-inflammatory (high-dose glucocorticoids and anti-interleukin treatments) treatments, and who were on chronic drug treatment with statins, were less likely to develop pericarditis or myocarditis. The clinical assessment of the participants showed clinical stability without any patient presenting severe pericardial effusion, heart failure or left ventricular dysfunction. We provide new data on seropositive subjects; although RT-PCR participants were more likely to still present symptoms than participants diagnosed by serology, the prevalence of pericarditis, myocarditis or myocarditis, almost three months after the initial viral prodrome, was high in both groups. Indepth investigation of the distribution of multiple major and minor populations of immune cells in blood showed high frequency of altered immune profiles after SARS-CoV-2 infection. The altered immune cell profiles identified partially mimic abnormalities previously reported during active infection together with others described here for the first time, with unique patterns associated with pericardial and/or myocardial injury. Nonetheless, we also described altered immune profiles in participants without pericardial and myocardial manifestations. Whether these later alterations are due to persistence of tissue damage in other organs affected by SARS$\mathrm{CoV}-2$, such as the lung, or they reflect normal post-infection immune recovery mechanisms, remains to be investigated.

\section{Implications of all the available evidence}

At present, there is much interest in the long-term sequelae of COVID-19. It is intriguing that pericarditis and myocarditis were observed so long after SARS-CoV-2 infection and also in some presently asymptomatic subjects, in association with notably altered immune cell profiles in blood. These observations will probably apply to the general population infected and may indicate that cardiac sequelae might occur late, paving the way for a better understanding the immune mechanisms involved. Thus, our study may have health-care consequences given the widespread diagnosis of SARS-CoV-2 infection in population-based seroprevalence studies. 
medRxiv preprint doi: https://doi.org/10.1101/2020.07.12.20151316; this version posted July 14, 2020. The copyright holder for this preprint

(which was not certified by peer review) is the author/funder, who has granted medRxiv a license to display the preprint in perpetuity.

It is made available under a CC-BY-NC-ND 4.0 International license .

Pericarditis and myocarditis long after SARS-CoV-2 infection: a cross-sectional

descriptive study in health-care workers

Eiros et al. 4 
medRxiv preprint doi: https://doi.org/10.1101/2020.07.12.20151316; this version posted July 14, 2020. The copyright holder for this preprint

(which was not certified by peer review) is the author/funder, who has granted medRxiv a license to display the preprint in perpetuity.

It is made available under a CC-BY-NC-ND 4.0 International license.

Pericarditis and myocarditis long after SARS-CoV-2 infection: a cross-sectional

descriptive study in health-care workers

Eiros et al. 5

\section{Introduction}

Pericarditis and myocarditis are the two most frequent cardiac manifestations observed after a viral infection ${ }^{1,2}$. Symptoms tend to be non-specific and most cases resolve without longterm sequelae. That is why the true incidence of pericarditis and myocarditis after common viral infections - influenza, parvovirus, coxsackievirus, echovirus, adenovirus, echovirus, herpesvirus or cytomegalovirus- is still unknown in the general population.

The novel severe acute respiratory syndrome-coronavirus-2 (SARS-CoV-2) is currently causing a sustained covid-19 pandemic, with the risk of causing long-term cardiac sequelae in the infected population ${ }^{3}$. The fear of SARS-CoV-2 causing greater myocardial damage than other conventional viruses is based on its mechanism of infecting human cells by binding to the transmembrane angiotensin-converting-enzyme- $2^{4}$, which is mainly expressed by cells in alveoli and myocardial tissue ${ }^{5}$; the rise in troponin levels observed in covid-19 patients hospitalized with pneumonia and its association with increased mortality ${ }^{6,7}$; and the probably reduced innate antiviral defences against a novel virus .

Pericarditis and myocarditis after conventional viral infections both stem from an inadequate or excessive immune response driven by $\mathrm{T}$ and $\mathrm{B}$ cell-mediated mechanisms ${ }^{1,2,9}$. In case of an inadequate response, continued viral replication in the peri-myocardium protracts inflammation by attracting killer $\mathrm{T}$ cells and the concomitant production of chemokines and cytokines. In contrast, molecular mimicry can result in the production of autoantibodies against cardiac proteins, leading to a cardio-specific autoimmune response that causes sustained inflammation, effusion or cardiac remodeling. However, the specific immune profiles that occur after SARS-CoV-2 infection, particularly in patients presenting with cardiac sequelae remain unknown ${ }^{10}$.

The present study was designed to search for evidence of pericardial and myocardial involvement after past SARS-CoV-2 infection comprehensively studied by clinical assessment, laboratory tests, electrocardiography and cardiac magnetic resonance (CMR) imaging. Additionally, participants underwent an in-depth characterization of the immune cell compartments in blood and the virus-specific humoral immune response in this clinical scenario. As health-care workers have been the group most affected by SARS-CoV-2 in Spain, but have also been subject to more testing than the rest of the population, we decided to conduct the study in this singular cohort.

\section{Methods}

\section{Study design and health-care workers participants}

This cross-sectional, observational, cohort study consecutively recruited 142 health-care workers with laboratory confirmed SARS-CoV-2 infection in Salamanca, Spain, and who volunteered for the study. Among them, 106 health-care workers tested positive for SARSCoV-2 by RT-PCR between March 13 and April 25; and 36 health-care workers were diagnosed after testing positive for anti-SARS-CoV-2-IgG antibodies between April 10 and May 22. The purpose of this second group was to also provide data from subjects with past SARS-CoV-2 infection in whom symptoms of viral infection are more likely to be mild and because population-based SARS-CoV-2 seroprevalence studies are becoming more established ${ }^{11,12}$. Study enrolment began on May 25 and finished on June 12, 2020.

Institutional approval (2020/05/490) for the study was provided by the University Hospital of Salamanca Ethics Committee, and all participants provided written informed consent. The study is registered with ClinicalTrials.gov NCT04413071. The responsibility for the study design, data collection and data interpretation lay solely with the study investigators. An internal adjudication monitoring board reviewed all cardiac study findings and adjudicated study outcomes. The authors had full access to all the data and elaborated all materials to submit for publication. 
medRxiv preprint doi: https://doi.org/10.1101/2020.07.12.20151316; this version posted July 14, 2020. The copyright holder for this preprint

(which was not certified by peer review) is the author/funder, who has granted medRxiv a license to display the preprint in perpetuity.

It is made available under a CC-BY-NC-ND 4.0 International license .

\section{Pericarditis and myocarditis long after SARS-CoV-2 infection: a cross-sectional descriptive study in health-care workers \\ Eiros et al. 6}

\section{Investigation process and procedures}

All participants underwent clinical evaluation, electrocardiography, laboratory tests and CMR imaging at the same visit. After obtaining written informed consent, trained interviewers used a structure questionnaire to collect baseline data in face-to-face interviews. A cardiologist took a complete medical history, performed a physical examination and reviewed the completeness of the questionnaire in a separate room, where an electrocardiogram was performed, and blood samples were drawn immediately before the CMR. Electrocardiograms were interpreted in consensus by two experienced readers, who were blinded to participant identification, clinical history, symptoms, physical examination and other findings.

CMR was performed using a clinical 1.5 whole-body magnetic resonance scanner in the cardiac imaging laboratory of the University Hospital of Salamanca ${ }^{13}$. Functional imaging was performed using standard segmented cine steady-state free-precession sequence with breath holding. Myocardial oedema was identified using a T2-weighted short-tau triple inversionrecovery (T2W-STIR) sequence. T2-relaxation time properties were obtained using a T2gradient spin-echo (T2-GraSE) mapping sequence. Assessment of T1-relaxation times and free water content within the myocardium (extracellular volume) were identified using a modified look-locker inversion recovery-MOLLI-with-5(3)3 acquisition scheme before and 15 minutes after intravenous administration of $0.15 \mathrm{mmol}$ per kg body weight of gadobutrol contrast media agent. Late gadolinium enhancement was identified on a series of T1-weighted inversion recovery turbo field echo sequence, acquired 10 to 15 minutes after the contrast administration. CMR images were globally and regionally analysed using dedicated software, in consensus by two experienced readers, who were blinded in a similar manner to the electrocardiogram protocol, following conventional CMR methods (supplementary methods). T2 and T1-based markers of myocardial inflammation were analysed in each of the 16 segments of the 17segment model of the American Heart Association (the true apex was excluded) ${ }^{14}$, where only positive segment concordances from the different $\mathrm{T} 2$ and T1-based markers were considered. Because myocarditis was diagnosed according to these T2 and T1-based CMR markers and an adequate selection of normal reference values is fundamental, we used as controls CMR imaging from 20-sex-and-aged matched individuals without cardiac disease from the general population of the province of Salamanca, Spain (NCT03429452) ${ }^{15}$.

Immunophenotypic analysis of ( $>250)$ immune cell populations was performed in peripheral blood samples collected in K3-EDTA $(10 \mathrm{~mL} / \mathrm{sample})$ and stained with the EuroFlow lymphocyte screening tube (LST) and the TCD4, NK/TCD8, BIgH and MoDC immune monitoring (IMM) tubes by flow cytometry (FACSCANTO II and LSR-Fortessa, respectively; Becton/Dickinson Biosciences, San José, California) using a dual-platform assay previously described in detail ${ }^{16,17}$. All protocols are available at www.euroflow.org. Reference values were defined based on a cohort of 463 age-matched adults (median age 52 years [IQR 47-61]) from the general population of the province of Salamanca, Spain. Anti-SARS-CoV-2-IgM (AnshLabs, Webster, Texas), IgG and IgA (Mikrogen Diagnostik, Neuried, Germany) antibody levels were measured in parallel in plasma from the same blood samples using commercially available IVD approved (semi-quantitative) ELISA kits, strictly as instructed by the manufacturers.

\section{Study outcomes and definitions}

Study outcome measures were the prevalence of pericarditis and of myocarditis. Pericarditis was diagnosed if at least two of the following criteria were present, following current guidelines ${ }^{1}$ : pericarditic chest pain, pericardial rub on auscultation, widespread STelevation or PR depression on ECG, and evidence of pericardial effusion at CMR. Elevation of inflammation markers, C-reactive protein, and evidence of pericardial inflammation at CMR were used as additional supporting findings. The diagnosis of myocarditis was based on the updated CMR Lake-Louis-Criteria (LLC) ${ }^{18}$, which consider as main LLC criteria for myocarditis positive oedema-sensitive T2-based markers (T2-weighted images or T2-mapping) 
medRxiv preprint doi: https://doi.org/10.1101/2020.07.12.20151316; this version posted July 14, 2020. The copyright holder for this preprint

(which was not certified by peer review) is the author/funder, who has granted medRxiv a license to display the preprint in perpetuity.

It is made available under a CC-BY-NC-ND 4.0 International license .

Pericarditis and myocarditis long after SARS-CoV-2 infection: a cross-sectional

descriptive study in health-care workers

Eiros et al. 7

or positive T1-based tissue characterization markers (abnormal T1-relaxation time or extracellular volume or late gadolinium enhancement), and as supportive LLC criteria either pericardial effusion, or evidence of pericardial inflammation at CMR, or systolic left ventricle wall motion abnormalities. Considering that participants were being examined beyond the acute phase of SARS-CoV-2 infection; myocarditis was defined as having a combination of at least two T2 or T1-based LLC main criteria or having a combination of only one T2 or T1-based LLC main criterion with one additional LLC supportive criterion.

As we were aware that pericarditis and myocarditis occur together in clinical practice, we hence defined as myopericarditis those cases of pericarditis with associated myocarditis on CMR but without left ventricle wall motion abnormalities, and as perimyocarditis those cases where left ventricle wall motion abnormalities were present ${ }^{19}$.

\section{Statistical Analysis}

Descriptive statistics were used to summarized the data; results are presented as the proportion (\%) of valid cases for categorical variables and as the median (IQR) for continuous variables. As the participants in our study were not randomly selected, all statistics are deemed descriptive only; nonetheless, differences between groups are also provided and were analysed by Fisher's exact test for categorical variables and by nonparametric Mann-Whitney or KruskalWallis for continuous data. We compared characteristics of participants and examinations, all Tables, according to the final clinical diagnosis (non-pericardial and myocardial manifestations vs pericarditis vs myopericarditis vs myocarditis). For 2-dimensional visualization of flow cytometry data, multivariate canonical analysis with multidimensional reduction of data via linear discriminant analysis, and the t-distributed stochastic neighbour embedding (t-SNE) machine-learning algorithm visualization tools, were used (Infinicyt software, Cytognos, Salamanca, Spain $)^{20}$.

\section{Results}

\section{Study Population}

Figure 1 depicts the flowchart for participant selection from the health-care workers. From the 142 recruited health-care workers who signed informed consent, one participant did not complete the CMR for claustrophobia. Two additional participants were excluded because history of severe hypertrophic myocardiopathy in one case, and inherited immune deficiency in the other. Thus, a total of 139 participants completed clinical assessment, electrocardiography, laboratory tests and CMR. Of these, 103 (74\%) had been diagnosed by RT-PCR and 36 (26\%) by serology.

All participant characteristics are shown in table 1. Median age was 52 years (41-57) and most were female, $100(72 \%)$. By professional categories, $49(35 \%)$ were nurses, $35(25 \%)$ medical doctors, and the remaining $55(40 \%)$ included different profiles such as auxiliary nurses and other hospital staff. A total of 67 (48\%) health-care workers were infected while directly attending covid-19 hospitalization wards.

Among the overall study population, $106(76 \%)$ had at least one comorbidity and 8 $(6 \%)$ health-care workers presented a history of cardiovascular disease; one with chronic ischemia with stent revascularization, three with paroxysmal atrial fibrillation, two with intranodal supraventricular tachycardias treated with ablation, and two with an episode of acute pericarditis several years before.

Most (137 [98\%]) health-care workers experienced a viral prodrome at SARS-CoV-2 infection. Fatigue was reported by 117 (84\%) participants, fever by 94 (68\%), cough by 91 (65\%), headache by $90(65 \%)$ and myalgia by $83(60 \%)$. Cardiac symptoms with shortness of breath, chest pain, palpitations or dizziness were reported by $86(62 \%)$ participants.

A total of $27(19 \%)$ health-care workers were previously diagnosed with covid-19 pneumonia and $23(16 \%)$ required hospitalization. Overall, the drug therapy aimed at 
medRxiv preprint doi: https://doi.org/10.1101/2020.07.12.20151316; this version posted July 14, 2020. The copyright holder for this preprint

(which was not certified by peer review) is the author/funder, who has granted medRxiv a license to display the preprint in perpetuity.

It is made available under a CC-BY-NC-ND 4.0 International license.

Pericarditis and myocarditis long after SARS-CoV-2 infection: a cross-sectional

descriptive study in health-care workers

Eiros et al. 8

ameliorating the disease was heterogeneous: hydroxychloroquine was given in 33 (24\%) cases, lopinavir-ritonavir in $17(12 \%)$, oral glucocorticoids in $9(6 \%)$, high-dose intravenous bolus of methylprednisolone in $15(11 \%)$, and interleukin inhibitors in $18(13 \%)$.

\section{Symptoms, electrocardiographic, biochemical, and cardiac magnetic resonance profiling}

The study examinations (table 2) were performed 10.4 (9.3-11.0) weeks after symptoms of infection began; $9 \cdot 4(8 \cdot 1-10 \cdot 0)$ weeks after the positive test for RT-PCR participants and $4.4(3.6-5 \cdot 0)$ weeks for participants diagnosed through antibodies testing.

All participants presented vital and exploratory signs of hemodynamic stability at examination. $91(65 \%)$ health-care workers still presented symptoms with fatigue being reported in $37(27 \%)$ cases, and those cardiac-related, such as shortness of breath in $36(26 \%)$ cases, chest pain in $27(19 \%)$, or palpitations in $20(14 \%)$.

Of the 139 electrocardiograms, electrocardiographic abnormalities were reported in 69 $(50 \%)$ cases. Minnesota codes abnormalities were observed in $49(35 \%)$ participants (supplementary table A), QT interval prolongation was observed in $5(4 \%)$, and early repolarization in $8(6 \%)$. A total of $33(24 \%)$ electrocardiograms met criteria for pericarditis-like changes (supplementary figure A).

Cardiac-specific and inflammatory biomarkers were within the normal range in most participants. Above the normal range, high-sensitivity troponin T concentration $(\geq 14$ pg. per millilitre) was increased in $1(1 \%)$ participant, NT-pro-BNP $(\geq 125 \mathrm{pg}$. per millilitre) in $11(8 \%)$ and C-reactive protein ( $\geq 3 \mathrm{mg}$. per decilitre) in $10(7 \%)$.

CMR abnormalities were observed in $104(75 \%)$ cases (complete data from CMR measures are in the supplementary tables B, C and D). $6(4 \%)$ participants presented increased of myocardial T2-relaxation time, $6(4 \%)$ oedema on T2-weighted images, $58(42 \%)$ increased native myocardial T1-relaxation time, 52 (37\%) increase of T1-extracellular volume, 10 (7\%) T1-late gadolinium enhancement, 42 (30\%) pericardial effusion, $1(1 \%)$ a pericardial thickness of $3 \mathrm{~mm}$ and 7 (5\%) systolic left ventricular wall motion abnormalities, global or regional (supplementary Figure B).

\section{Pericarditis and myocarditis prevalence}

A total of 55 (40\%) participants fulfilled criteria for either pericarditis or myocarditis. Among them, 19 (14\%) fulfilled criteria for pericarditis, 51 (37\%) criteria for myocarditis, and $15(11 \%)$ fulfilled criteria for both pericarditis and myocarditis.

Of the 19 participants fulfilling criteria for pericarditis, 15 (79\%) presented two classical criteria and $4(21 \%)$ three criteria. Of the 51 participants fulfilling criteria for myocarditis, $22(43 \%)$ presented a combination of at least two T2 or T1-based LLC main criteria and $29(57 \%)$ presented a combination of only one T2 or T1-based LLC main criterion with at least one additional LLC supportive criterion. Additional descriptions of criteria combinations are provided in figure 2.

Clinical isolated pericarditis was then diagnosed in 4 (3\%) cases, myopericarditis in 15 $(11 \%)$ and isolated myocarditis in $36(26 \%)$. Baseline and examination characteristics for each diagnostic group are detailed in tables 1 and $\mathbf{2}$.

A higher percentage of participants without pericardial or myocardial manifestations than participants with pericarditis, myopericarditis and myocarditis were on chronic drug therapy with statins (16 [19\%] vs. 1 [2\%]; $\mathrm{p}=0.003$ ), were previously hospitalized for covid-19 $(19[23 \%]$ vs. 4 [7\%]; $\mathrm{p}=0.020)$, and received drug therapy aimed at ameliorating the disease: hydroxychloroquine (25 [30\%] vs. 8 [14\%]; p=0.043), lopinavir-ritonavir (14 [17\%] vs. 3 [5\%]; $\mathrm{p}=0.064)$ and interleukin inhibitors or high-doses of intravenous glucocorticoids $(16$ [19\%] vs. 4 [7\%]; $p=0.082$ ). A higher percentage of participants with pericarditis, myopericarditis or myocarditis than participants without these manifestations presented cardiac symptoms at SARS-CoV-2 infection (40 [73\%] vs. 46 [55\%]; p=0.049) and at study examination (30 [54\%] vs. 28 [33\%]; p=0.015). 
medRxiv preprint doi: https://doi.org/10.1101/2020.07.12.20151316; this version posted July 14, 2020. The copyright holder for this preprint

(which was not certified by peer review) is the author/funder, who has granted medRxiv a license to display the preprint in perpetuity.

It is made available under a CC-BY-NC-ND 4.0 International license .

Pericarditis and myocarditis long after SARS-CoV-2 infection: a cross-sectional

descriptive study in health-care workers

Eiros et al. 9

\section{Participants with infection confirmed through anti-SARS-CoV-2-IgG detection}

Among the participants diagnosed with past infection through anti-SARS-CoV-2-IgG detection (data for this group, compared to RT-PCR participants, are shown in the appendix [supplementary table E), 28 (78\%) were previously tested negative by RT-PCR after developing mild SARS-CoV-2 symptoms and 8 (22\%) were never RT-PCR tested. A lower percentage of participants diagnosed through positive serology still presented symptoms at examination compared to RT-PCR participants (18 [50\%] vs. 73 [71\%]; $\mathrm{p}=0.027)$; nonetheless, the prevalence of pericarditis, myopericarditis or myocarditis was high in both groups (figure 3 ).

\section{Altered immune cell and humoral profiles in blood}

Most study participants (101 [73\%]) displayed altered cell counts in blood for at least one major immune cell population as illustrated in figure $\mathbf{4 A - B}$, and described in more detail in tables 3 and 4. Most frequent alterations consisted of eosinopenia (38 [27\%] cases; $p<0.001$ ), and increased $\mathrm{CD} 4 \mathrm{CD}^{-/ / \mathrm{lo}} \mathrm{T} \alpha \beta$ (cytotoxic) T-cell (24 [17\%] cases; $\mathrm{p}<0.001$ ); and, to a less extent also B-cell counts (16 [12\%] cases; $\mathrm{p}<0.001)$. In addition, compared to age-matched healthy donors, participants had higher median counts in blood of basophils ( $38 \mathrm{vs} .47 \mathrm{cells} / \mu \mathrm{L}$, respectively; $\mathrm{p}<0.013$ ), total monocytes ( $317 \mathrm{vs} 405$ cells $/ \mu \mathrm{L} ; \mathrm{p}<0.001$ ) at the expense of classical (FceRI') monocytes (290 vs 386 cells/ $\mu \mathrm{L} ; \mathrm{p}<0.001$ ), total lymphocytes (1675 vs 2221 cells $/ \mu \mathrm{L} ; \mathrm{p}<0.001$ ), including total T-lymphocytes (1246 vs 1652 cells $/ \mu \mathrm{L} ; \mathrm{p}<0.001$ ), TCD4 (716 vs 1017 cells/ $\mu \mathrm{L} ; \mathrm{p}<0.001)$, TCD8 (407 vs 507 cells/ $\mu \mathrm{L} ; \mathrm{p}<0.001)$ and B lymphocytes (154 vs 208 cells $/ \mu \mathrm{L} ; \mathrm{p}<0.001)$; in contrast, participants showed decreased median numbers of circulating blood myeloid-derived suppressor cells ( 5 vs 2 cells $/ \mu \mathrm{L} ; \mathrm{p}<0.001$, immature CD16CD62 $\mathrm{L}^{-}$neutrophils (5 vs 2 cells $/ \mu \mathrm{L} ; \mathrm{p}<0.001$ ), intermediate monocytes (20 vs 14 cells $/ \mu \mathrm{L}$; $\mathrm{p}=0.001)$ and immunomodulatory FceRI ${ }^{+} \mathrm{CD}_{2} \mathrm{~L}^{+}(46$ vs $12 ; \mathrm{p}=0.038)$ and FceRI ${ }^{+} \mathrm{CD}_{2} \mathrm{~L}^{-}$(7 vs $2 ; \mathrm{p}=0.001)$ monocytes, plasmacytoid dendritic cells ( 8 vs 6 cells $/ \mu \mathrm{L} ; \mathrm{p}=0.020)$, NK-cells (260 vs 213 cells $/ \mu \mathrm{L} ; \mathrm{p}=0.007$ ) and circulating plasma cells ( 2 vs 0.8 cells $/ \mu \mathrm{L} ; \mathrm{p}<0.001$ ).

Compared to healthy donors, participants with pericarditis showed the highest median counts in blood of $\mathrm{CD} 4{ }^{-} \mathrm{CD}^{-/ / \mathrm{lo}} \mathrm{T} \alpha \beta$ (cytotoxic) T-cells (46 vs 137 cells $/ \mu \mathrm{L} ; \mathrm{p}=0.011$ ) and also displayed (similarly to cases with myopericarditis and those with myocarditis) decreased blood counts of FceRI ${ }^{+} \mathrm{CD} 62 \mathrm{~L}^{+}$immunomodulatory monocytes (46 vs 4, 2 and 11, respectively; $\mathrm{p}=0.020$ ).

Participants diagnosed with myopericarditis tended to share altered immune cell profiles with myocarditis, except for two cases with myopericarditis whose profiles more closely overlapped with those cases with pericarditis (figure 4B). Thus, compared to healthy donors, participants with myopericarditis and those with myocarditis specifically displayed more pronounced decreased counts in blood of plasmacytoid dendritic cells ( 8 vs 6 and 5 cells $/ \mu \mathrm{L}$, respectively; $\mathrm{p}<0.001$ ), and NK-cells (260 vs 120 and 177 cells $/ \mu \mathrm{L} ; \mathrm{p}<0.001$ ), including the subset of cytotoxic granzyme B $(\mathrm{Gz})^{+} \mathrm{CD} 57^{-}$of NK-cell, $\mathrm{T} \gamma \delta$ and/or TCD8 cells (supplementary table F), and circulating plasma cells ( 2 vs 0.4 and 1 cells $/ \mu \mathrm{L} ; \mathrm{p}<0.001$ ) (supplementary table $\mathrm{G})$.

Finally, participants with myopericarditis and those with myocarditis presented lower amounts of anti-SARS-CoV-2-IgG antibodies (115 [42-156] and 114 [77-160] IU/mL, respectively) compared to participants without pericardial or myocardial manifestations (147 [93-176] IU/mL; $\mathrm{p}=0.027$ ) (figure 4C). Of note, among participants with myopericarditis, the above alterations were further associated with lower TCD4 Th17 lymphocytes (20 vs 33 cells $/ \mu \mathrm{L} ; \mathrm{p}=0.023$ ) (supplementary table $\mathrm{H}$ ).

\section{Discussion}


medRxiv preprint doi: https://doi.org/10.1101/2020.07.12.20151316; this version posted July 14, 2020. The copyright holder for this preprint

(which was not certified by peer review) is the author/funder, who has granted medRxiv a license to display the preprint in perpetuity. It is made available under a CC-BY-NC-ND 4.0 International license.

\section{Pericarditis and myocarditis long after SARS-CoV-2 infection: a cross-sectional descriptive study in health-care workers \\ Eiros et al. 10}

This study examined the prevalence of pericarditis and of myocarditis in a cohort of SARS-CoV-2 positive health-care workers in Salamanca, Spain. In the largest cohort of subjects with CMR imaging assessment reported so far, we demonstrate that pericardial and myocardial involvement is highly prevalent after SARS-CoV-2 infection.

We decided to carry out a study in health-care workers, as this sector has been disproportionally infected in Spain —approximately 20\% of all COVID-19 cases ${ }^{21}$ — which provided us with the opportunity to study the prevalence of pericarditis and myocarditis in SARS-CoV-2 infected cases that were confirmed by positive RT-PCR or positive serology. In addition, as the proportion of female health-care workers is high in Spain, our study does not underrepresent women who constituted more than two thirds of recruited participants. Unlike other observational studies suggesting that myocarditis may be slightly more prevalent in men than women ${ }^{22-24}$; men in our study presented lower prevalence of pericarditis or myocarditis than women $(11[28 \%]$ vs. 44 [44\%]; $\mathrm{p}=0.122)$. This observation could be related, more than to gender, to the higher rate of previous hospitalization for COVID-19 pneumonia in men than women (13 [33\%] vs. 10 [10\%]; $\mathrm{p}=0.002)$ for our cohort. In general, previously hospitalized participants presented lower percentage of pericardial and myocardial injury compared to participants never hospitalized (4 [17\%] vs. 51 [44\%]; p=0.020). Having been hospitalized, participants received more treatment aimed at inhibiting viral replication (lopinavir-ritonavir or hydroxychloroquine) and reducing inflammation (high-dose glucocorticoids and interleukin inhibitors). The recent Recovery study (NCT04381936) has shown that low-dose dexamethasone reduces mortality in hospitalized COVID-19 patients.

Case reports of myocarditis and pericarditis have been published during the COVID-19 hospitalization phase ${ }^{25}$. A recent retrospective observation in 26 recovered patients with COVID-19 pneumonia presenting cardiac complaints during hospitalization, revealed the presence of myocardial oedema in $14(54 \%)$ patients and late gadolinium enhancement in 8 (31\%) patients ${ }^{26}$. Our results are in agreement with these findings as $89(64 \%)$ of our participants presented myocardial injury in T2 or in T1-based CMR. High rates of myocardial damage are also observed in influenza — where elevated cardiac enzymes, electrocardiographic, echocardiographic and histologic findings have been reported in approximately one third of $\operatorname{cases}^{27}$.

Importantly, clinical assessment of our participants with pericarditis and myocarditis showed clinical stability without any participant presenting severe pericardial effusion, heart failure or left ventricular dysfunction (only four participants with myocarditis presented wall motion abnormalities). However, follow-up studies are necessary to determine the outcome of cardiac sequelae observed even in asymptomatic and pauci-symptomatic subjects after SARSCoV-2 infection ${ }^{28}$. Thus, the participants diagnosed of past infection through serology who were more likely to be asymptomatic or mildly symptomatic, and who might better represent the cases detected in population-wide seroprevalence studies ${ }^{11,12}$, presented a similar prevalence of pericardial and myocardial manifestations to RT-PCR positive participants (11 [31\%] vs 44 [43\%]; $\mathrm{p}=0.238$ ).

At present, there is much interest in the long-term sequelae of COVID-19. It is intriguing that pericarditis, myopericarditis or myocarditis were observed that long after SARSCoV-2 infection (over 10 weeks after initial viral prodrome at infection) and also in some presently asymptomatic subjects ( $15[11 \%]$ of the study population; one every three-final pericarditis, myopericarditis or myocarditis diagnosis). These long-term manifestations may be due to an inadequate innate and adaptative immune response. In recent months, important advances have been achieved in the understanding of the immunology of COVID-19 ${ }^{10}$. However, there is still very limited data on the longer-term immunological consequences of past SARS-CoV-2 infection, and no study has specifically focused in the settings of pericarditis and myocarditis. Herein, in-depth investigation of the distribution of major and minor populations of immune cells in blood showed a high frequency of overall altered immune profiles. Several of the immune cell alterations identified mimic abnormalities reported during active infection, including decreased eosinophil, NK-cell, and (plasmacytoid) dendritic cell counts ${ }^{29,30}$. In 
medRxiv preprint doi: https://doi.org/10.1101/2020.07.12.20151316; this version posted July 14, 2020. The copyright holder for this preprint

(which was not certified by peer review) is the author/funder, who has granted medRxiv a license to display the preprint in perpetuity.

It is made available under a CC-BY-NC-ND 4.0 International license .

\section{Pericarditis and myocarditis long after SARS-CoV-2 infection: a cross-sectional descriptive study in health-care workers \\ Eiros et al. 11}

contrast, other alterations are described here for the first time and have not been reported during the acute phase of the infection. These new alterations include abnormally high numbers of monocytes (i.e. recently produced classical monocytes) and lymphocytes, such as T-cells, particularly $\mathrm{CD} 4 \mathrm{CD} 8^{-1 / 0}$, TCD4 cells and TCD8 cells, and B-lymphocytes together with decreased counts of myeloid-derived suppressor cells, immature (CD16-CD62L-) neutrophils, both immunomodulatory FceRI ${ }^{+} \mathrm{CD} 62 \mathrm{~L}^{+}$and intermediate (i.e. CD14+CD16+) monocytes and circulating plasma cells. Altogether, these findings may partially reflect (the normal and an altered) immune recovery after SARS-CoV-2 infection. Thus, while persistence of eosinopenia and expansion of $\mathrm{CD} 4 \mathrm{CD} 8^{-/ l o} \mathrm{~T}$-cells in blood were detected across all groups of participants suggesting it is part of the immune recovery after COVID-19; NK-cells were specifically decreased among participants with myopericarditis and myocarditis in association with (persistent) tissue damage. Nonetheless, the altered immune profiles in participants without pericardial and myocardial manifestations, could also be due to persistence of tissue damage and recovery in other organs affected by SARS-CoV-2, such as the lung, more than just reflecting normal immune recovery. Anyhow, more detailed analysis of the altered immune profiles among the different groups of participants showed that those with myopericarditis or myocarditis had closer to normal lymphocyte counts, but reduced numbers in blood of circulating eosinophils, plasmacytoid dendritic cells and particularly, NK-cells. Such unique profile mimics what has been described recently during the acute phase of SARS-CoV-2 infection, suggesting an ongoing cytotoxic response with increased tissue migration or death by apoptosis of specific subsets of cytotoxic cells. In line with this hypothesis, we found here lower numbers of granzymeB+CD57- memory and effector TCD8-, T $\gamma \delta$ - and/or NK-cells among participants with myopericarditis or myocarditis. Of note, these participants with myocardial injury also showed particularly lower counts in blood of (recently produced) plasma cells, together with lower anti-SARS-CoV-2-IgG plasma levels. These findings suggest that a less pronounced (potentially insufficient) or a delayed humoral response may occur in these subjects, which may lead to decreased neutralization, opsonization and/or clearance of the virus locally at the peri-myocardium; local viral persistence would favour an increased tissue-homing (or early death) of eosinophils, immunomodulatory and intermediate monocytes, in addition to cytotoxic (effector) cells. Altogether, the above findings suggest that an inadequate (potentially delayed) immune response might happen in a substantial fraction of patients with past SARSCoV-2 infection, with differently altered profiles in subjects who present myopericarditis or myocarditis.

\section{Limitations of the study}

The study analysis was limited to health-care workers in Salamanca and therefore may have limited external generalizability to other non-health-care settings. However, the strength of this study is the addition of non-hospitalized participants and also the inclusion of participants diagnosed of past SARS-CoV-2 infection through serology, who also had a high prevalence of pericarditis and myocarditis. Seropositive participants, although less symptomatic than RT-PCR participants, presented mild symptoms in almost all cases; unfortunately, we cannot draw conclusions regarding the prevalence of pericarditis and myocarditis in the completely asymptomatic general population. Finally, the study relied solely on descriptive observations and cannot provide any conclusion on the benefit of antiviral and anti-inflammatory treatments during the acute phase of infection or whether the prevalence of pericarditis and myocarditis after SARS-CoV-2 infection is higher in women than men.

\section{Conclusions}

This study shows that pericarditis and myocarditis are frequent long after SARS-CoV-2 infection and also in some presently asymptomatic subjects; in addition, we provide herein evidence for an altered immune cell distribution in blood which affects cells involved in both the innate (e.g. eosinophils and monocytes) and the adaptative cellular (e.g. $\mathrm{CD} 4{ }^{-} \mathrm{CD} 8^{-/ 10} \mathrm{~T} \alpha \beta^{+}$, TCD4 and TCD8 T-cells) and humoral (e.g. plasma cells and anti-Sars-CoV-2 IgG levels) 
medRxiv preprint doi: https://doi.org/10.1101/2020.07.12.20151316; this version posted July 14, 2020. The copyright holder for this preprint

(which was not certified by peer review) is the author/funder, who has granted medRxiv a license to display the preprint in perpetuity.

\section{It is made available under a CC-BY-NC-ND 4.0 International license .}

Pericarditis and myocarditis long after SARS-CoV-2 infection: a cross-sectional descriptive study in health-care workers

Eiros et al. 12

immune responses; nonetheless, a direct link between such altered immune profiles and the presence of pericardial and myocardial injury still needs to be established. These observations will probably apply to the general population infected, and may indicate that cardiac sequelae might occur late. Although all study participants presented clinical stability and non-severe cardiac complications, prospective monitoring will be necessary to address the future clinical consequences of these findings. 
medRxiv preprint doi: https://doi.org/10.1101/2020.07.12.20151316; this version posted July 14, 2020. The copyright holder for this preprint

(which was not certified by peer review) is the author/funder, who has granted medRxiv a license to display the preprint in perpetuity.

It is made available under a CC-BY-NC-ND 4.0 International license .

Pericarditis and myocarditis long after SARS-CoV-2 infection: a cross-sectional

descriptive study in health-care workers

Eiros et al. 13

\section{References}

1. Adler Y, Charron P, Imazio M, et al. 2015 ESC Guidelines for the diagnosis and management of pericardial diseases: The Task Force for the Diagnosis and Management of Pericardial Diseases of the European Society of Cardiology (ESC)Endorsed by: The European Association for Cardio-Thoracic Surgery (EACTS). Eur Heart J 2015; 36(42): 2921-64.

2. $\quad$ Sagar S, Liu PP, Cooper LT. Myocarditis. Lancet 2012; 379(9817): 738-47.

3. Driggin E, Madhavan MV, Bikdeli B, et al. Cardiovascular Considerations for Patients, Health Care Workers, and Health Systems During the COVID-19 Pandemic. J Am Coll Cardiol 2020; 75(18): 2352-71.

4. Hoffmann M, Kleine-Weber H, Schroeder S, et al. SARS-CoV-2 Cell Entry Depends on ACE2 and TMPRSS2 and Is Blocked by a Clinically Proven Protease Inhibitor. Cell 2020; 181(2): 271-80.e8.

5. Guzik TJ, Mohiddin SA, Dimarco A, et al. COVID-19 and the cardiovascular system: implications for risk assessment, diagnosis, and treatment options. Cardiovasc Res 2020.

6. Shi S, Qin M, Cai Y, et al. Characteristics and clinical significance of myocardial injury in patients with severe coronavirus disease 2019. Eur Heart J 2020.

7. Petrilli CM, Jones SA, Yang J, et al. Factors associated with hospital admission and critical illness among 5279 people with coronavirus disease 2019 in New York City: prospective cohort study. BMJ 2020; 369: m1966.

8. Blanco-Melo D, Nilsson-Payant BE, Liu WC, et al. Imbalanced Host Response to SARS-CoV-2 Drives Development of COVID-19. Cell 2020; 181(5): 1036-45.e9.

9. Siripanthong B, Nazarian S, Muser D, et al. Recognizing COVID-19-related myocarditis: the possible pathophysiology and proposed guideline for diagnosis and management. Heart Rhythm 2020.

10. Vabret N, Britton GJ, Gruber C, et al. Immunology of COVID-19: Current State of the Science. Immunity 2020; 52(6): 910-41.

11. Stringhini S, Wisniak A, Piumatti G, et al. Seroprevalence of anti-SARS-CoV-2 IgG antibodies in Geneva, Switzerland (SEROCoV-POP): a population-based study. Lancet 2020.

12. Pollan M, Perez-Gomez B, Pastor-Barriuso R, et al. Prevalence of SARS-CoV-2 in Spain (ENECOVID): a nationwide, population-based seroepidemiological study. Lancet 2020.

13. Barreiro-Pérez M, Tundidor-Sanz E, Martín-García A, et al. First Magnetic Resonance Managed by a Cardiology Department in the Spanish Public Healthcare System. Experience and Difficulties of an Innovative Model. Rev Esp Cardiol (Engl Ed) 2018; 71(5): 365-72.

14. Cerqueira MD, Weissman NJ, Dilsizian V, et al. Standardized myocardial segmentation and nomenclature for tomographic imaging of the heart. A statement for healthcare professionals from the Cardiac Imaging Committee of the Council on Clinical Cardiology of the American Heart Association. Circulation 2002; 105(4): 539-42.

15. Melero-Alegria JI, Cascon M, Romero A, et al. SALMANTICOR study. Rationale and design of a population-based study to identify structural heart disease abnormalities: a spatial and machine learning analysis. BMJ Open 2019; 9(2): e024605. 
medRxiv preprint doi: https://doi.org/10.1101/2020.07.12.20151316; this version posted July 14, 2020. The copyright holder for this preprint

(which was not certified by peer review) is the author/funder, who has granted medRxiv a license to display the preprint in perpetuity.

It is made available under a CC-BY-NC-ND 4.0 International license .

\section{Pericarditis and myocarditis long after SARS-CoV-2 infection: a cross-sectional descriptive study in health-care workers \\ Eiros et al. 14}

16. van Dongen JJ, Lhermitte L, Böttcher S, et al. EuroFlow antibody panels for standardized ndimensional flow cytometric immunophenotyping of normal, reactive and malignant leukocytes. Leukemia 2012; 26(9): 1908-75.

17. Botafogo V, Pérez-Andres M, Jara-Acevedo M, et al. Age Distribution of Multiple Functionally Relevant Subsets of CD4+ T Cells in Human Blood Using a Standardized and Validated 14-Color EuroFlow Immune Monitoring Tube. Front Immunol 2020; 11: 166.

18. Ferreira VM, Schulz-Menger J, Holmvang G, et al. Cardiovascular Magnetic Resonance in Nonischemic Myocardial Inflammation: Expert Recommendations. J Am Coll Cardiol 2018; 72(24): 3158-76.

19. Chiabrando JG, Bonaventura A, Vecchié A, et al. Management of Acute and Recurrent Pericarditis: JACC State-of-the-Art Review. J Am Coll Cardiol 2020; 75(1): 76-92.

20. Flores-Montero J, Grigore G, Fluxá R, et al. EuroFlow Lymphoid Screening Tube (LST) data base for automated identification of blood lymphocyte subsets. J Immunol Methods 2019; 475: 112662.

21. Instituto de Salud Carlos III. Casos COVID-19 en personal sanitario hasta el 10 de mayo (situación a 29 de mayo de 2020). Available from:

https://www.isciii.es/QueHacemos/Servicios/VigilanciaSaludPublicaRENAVE/EnfermedadesTransmisibl es/Documents/INFORMES/Informes\%20COVID-19/COVID19\%20en\%20personal\%20sanitario $\% 2029 \% 20 \mathrm{de} \% 20$ mayo $\% 20 \mathrm{de} \% 202020$.pdf.

22. Shah Z, Mohammed M, Vuddanda V, Ansari MW, Masoomi R, Gupta K. National Trends, Gender, Management, and Outcomes of Patients Hospitalized for Myocarditis. Am J Cardiol 2019; 124(1): 131-6.

23. Kytö V, Sipilä J, Rautava P. The effects of gender and age on occurrence of clinically suspected myocarditis in adulthood. Heart 2013; 99(22): 1681-4.

24. Caforio AL, Calabrese F, Angelini A, et al. A prospective study of biopsy-proven myocarditis: prognostic relevance of clinical and aetiopathogenetic features at diagnosis. Eur Heart J 2007; 28(11): 1326-33.

25. Imazio M, Klingel K, Kindermann I, et al. COVID-19 pandemic and troponin: indirect myocardial injury, myocardial inflammation or myocarditis? Heart 2020.

26. Huang L, Zhao P, Tang D, et al. Cardiac involvement in recovered COVID-19 patients identified by magnetic resonance imaging. JACC: Cardiovascular Imaging 2020.

27. Sellers SA, Hagan RS, Hayden FG, Fischer WA. The hidden burden of influenza: A review of the extra-pulmonary complications of influenza infection. Influenza Other Respir Viruses 2017; 11(5): 372-93.

28. Treibel TA, Manisty C, Burton M, et al. COVID-19: PCR screening of asymptomatic health-care workers at London hospital. Lancet 2020; 395(10237): 1608-10.

29. Qin C, Zhou L, Hu Z, et al. Dysregulation of immune response in patients with COVID-19 in Wuhan, China. Clin Infect Dis 2020.

30. Chen R, Sang L, Jiang M, et al. Longitudinal hematologic and immunologic variations associated with the progression of COVID-19 patients in China. J Allergy Clin Immunol 2020. 
medRxiv preprint doi: https://doi.org/10.1101/2020.07.12.20151316; this version posted July 14, 2020. The copyright holder for this preprint

(which was not certified by peer review) is the author/funder, who has granted medRxiv a license to display the preprint in perpetuity.

It is made available under a CC-BY-NC-ND 4.0 International license .

Pericarditis and myocarditis long after SARS-CoV-2 infection: a cross-sectional

descriptive study in health-care workers

Eiros et al. 15

\section{Figure legends}

Figure 1: Flowchart for participant selection among health-care workers. All clinical suspicions of SARS-CoV-2 infection, RT-PCR and anti-SARS-CoV-2 antibodies test management, result information, and preventive and isolation actions for Salamanca's healthcare workers have been managed through the Occupational Health Service from the University Hospital of Salamanca during the COVID-19 pandemic; making it easy to identify health-care workers candidates for the study.

Figure 2: Pericarditis, myopericarditis and myocarditis criteria combinations. Description of pericarditis clinical criterions and updated Lake-Louise-Criteria for myocarditis in participants diagnosed with pericarditis, myopericarditis or myocarditis. $\mathrm{CRP}=\mathrm{C}$-reactive protein; $\mathrm{ECG}=$ electrocardiogram; $\mathrm{ECV}=$ increase of $\mathrm{T} 1$-extracellular volume; Effusion= pericardial effusion assessed at cardiac magnetic resonance; $L G E=T 1$-late gadolinium enhancement; $\mathrm{LV}=$ systolic left ventricular wall motion abnormalities; T1 map= increase of native myocardial T1-relaxation time; T2 map= increase of myocardial T2-relaxation time; $\mathrm{T} 2 \mathrm{~W}=$ increase of $\mathrm{T} 2$-weighted hyperintensity; Thickened= pericardial thickness greater or equal to $3 \mathrm{~mm}$.

Figure 3: Pericarditis and myocarditis prevalence by SARS-CoV-2 infection laboratory diagnosis. Prevalence of pericarditis or myocarditis, pericarditis, myopericarditis and myocarditis in participants with SARS-CoV-2 infection diagnosed through RT-PCR or through serology.

Figure 4: Altered immune cell profiles and antibody serum levels in the health-care workers grouped according to the presence vs absence of pericarditis, myopericarditis and myocarditis. A: t-SNE graphical representation of the distribution of the major immune cell populations in blood of a healthy donor (T-SNE plot in the left) and a participant diagnosed with pericarditis (t-SNE middle plot) showing both increased Tab+CD4-CD8-/lo T cell and decreased eosinophil counts in blood. B: 2-dimension graphical representation of multivariate canonical (linear discriminant) analysis plots showing the presence of overall different immune cell profiles in blood of the participants with past SARS-CoV-2 infection ( $\mathrm{n}=139$; coloured circles) vs age-matched healthy donors ( $n=463$; grey squares) (two plots in the left); distinct immune cell profiles were also observed between participants diagnosed with pericarditis (blue circles) and myocarditis (orange circles); most myopericarditis cases (red circles) shared an altered immune cell profile in blood similar to that of myocarditis. C: Frequency and amount of anti-SARS-CoV-2 antibodies measured in plasma of 123/139 participants grouped according to the absence vs presence of pericarditis, myopericarditis and myocarditis. 
Tables

Table 1. Baseline characteristics of the study cohort

\begin{tabular}{|c|c|c|c|c|c|c|}
\hline & \multirow{2}{*}{$\begin{array}{l}\text { All participants } \\
\qquad(\mathrm{N}=139)\end{array}$} & \multicolumn{4}{|c|}{ Presence of pericardial and myocardial manifestations } & \multirow[t]{2}{*}{$p$ value } \\
\hline & & $\begin{array}{c}\text { No } \\
(N=84)\end{array}$ & $\begin{array}{c}\text { Pericarditis } \\
\quad(n=4)\end{array}$ & $\begin{array}{c}\text { Myopericarditis } \\
(\mathrm{N}=15)\end{array}$ & $\begin{array}{l}\text { Myocarditis } \\
(\mathrm{N}=36)\end{array}$ & \\
\hline Median (range) age (years) & $52(41-57)$ & $52(38-57)$ & $45(34-52)$ & $54(44-60)$ & $52(48-57)$ & 0.503 \\
\hline Female sex & $100(72)$ & $56(67)$ & $3(75)$ & $12(80)$ & $29(81)$ & 0.400 \\
\hline Health care worker category & & & & & & 0.669 \\
\hline Medical staff & $35(25)$ & $22(26)$ & $1(25)$ & $6(40)$ & $6(17)$ & \\
\hline Nurse & $49(35)$ & $28(33)$ & $1(25)$ & $4(27)$ & $16(44)$ & \\
\hline Other & $55(40)$ & $34(40)$ & $2(50)$ & $5(33)$ & $14(39)$ & \\
\hline Direct attention to COVID-19 patients & $67(48)$ & $40(48)$ & $3(75)$ & $7(47)$ & $17(47)$ & 0.814 \\
\hline \multicolumn{7}{|l|}{ Coexisting conditions } \\
\hline Obesity" & $17(12)$ & $14(17)$ & $1(25)$ & 0 & $2(6)$ & 0.108 \\
\hline Hypertension & $17(12)$ & $11(13)$ & $1(25)$ & $1(7)$ & $4(11)$ & 0.679 \\
\hline Diabetes & $2(1)$ & $2(2)$ & 0 & 0 & 0 & 1.000 \\
\hline Dyslipidaemia & $27(19)$ & $17(20)$ & $1(25)$ & $2(13)$ & $7(19)$ & 0.936 \\
\hline Current smoking & $6(4)$ & $4(5)$ & 0 & $1(7)$ & $1(3)$ & 0.741 \\
\hline Past smoking & $70(50)$ & $43(51)$ & 0 & $6(40)$ & $21(58)$ & 0.140 \\
\hline Alcohol use $e^{\dagger}$ & $23(16)$ & $10(12)$ & $1(25)$ & $3(20)$ & $9(25)$ & 0.217 \\
\hline Cardiovascular disease & $8(6)$ & $5(6)$ & 0 & $2(13)$ & $1(3)$ & 0.472 \\
\hline Pulmonary disease & $8(6)$ & $5(6)$ & 0 & 0 & $3(8)$ & 0.805 \\
\hline Sleep apnoea-hypopnea syndrome & $8(6)$ & $5(6)$ & 0 & $2(13)$ & $1(3)$ & 0.472 \\
\hline Chronic kidney disease & $5(4)$ & $2(2)$ & 0 & 0 & $3(8)$ & 0.319 \\
\hline Cancer & $4(3)$ & $3(4)$ & 0 & 0 & $1(3)$ & 1.000 \\
\hline Al least of the above & $106(76)$ & $64(76)$ & $3(75)$ & $9(60)$ & $30(83)$ & 0.287 \\
\hline Daily physical activity & $86(62)$ & $47(56)$ & $3(75)$ & $11(73)$ & $25(69)$ & 0.376 \\
\hline
\end{tabular}




\begin{tabular}{|c|c|c|c|c|c|c|}
\hline & \multirow{2}{*}{$\begin{array}{l}\text { All participants } \\
\qquad(\mathrm{N}=139)\end{array}$} & \multicolumn{4}{|c|}{ Presence of pericardial and myocardial manifestations } & \multirow[t]{2}{*}{$\mathrm{p}$ value } \\
\hline & & $\begin{array}{c}\text { No } \\
(\mathrm{N}=84)\end{array}$ & $\begin{array}{l}\text { Pericarditis } \\
\quad(n=4)\end{array}$ & $\begin{array}{l}\text { Myopericarditis } \\
(\mathrm{N}=15)\end{array}$ & $\begin{array}{l}\text { Myocarditis } \\
(\mathrm{N}=36)\end{array}$ & \\
\hline SARS-CoV-2 infection diagnosis & & & & & & 0.274 \\
\hline RT-PCR & $103(74)$ & $59(70)$ & $3(75)$ & $14(93)$ & $27(75)$ & \\
\hline Anti-SARS-CoV-2-IgG antibodies & $36(26)$ & $25(30)$ & $1(25)$ & $1(7)$ & $9(25)$ & \\
\hline \multicolumn{7}{|l|}{ Symptoms at SARS-CoV-2 infection } \\
\hline \multicolumn{7}{|l|}{ General } \\
\hline Fatigue & $117(84)$ & $68(81)$ & $3(75)$ & $14(93)$ & $32(89)$ & 0.453 \\
\hline Fever & $94(68)$ & $60(71)$ & $4(100)$ & $12(80)$ & $18(50)$ & $0.044^{* *}$ \\
\hline Cough & $91(65)$ & $57(68)$ & $3(75)$ & $10(67)$ & $21(58)$ & 0.768 \\
\hline Headache & $90(65)$ & $52(62)$ & $2(50)$ & $11(73)$ & $25(69)$ & 0.697 \\
\hline Myalgia & $83(60)$ & $46(55)$ & $4(100)$ & $9(60)$ & $24(67)$ & 0.255 \\
\hline Anosmia & $73(52)$ & $41(49)$ & $3(75)$ & $9(60)$ & $20(56)$ & 0.643 \\
\hline Ageusia & $66(47)$ & $34(40)$ & $3(75)$ & $7(47)$ & $22(61)$ & $0.133^{* *}$ \\
\hline Abdominal pain or diarrhoea & $64(46)$ & $37(44)$ & $1(25)$ & $7(47)$ & $19(53)$ & 0.722 \\
\hline Chills & $60(43)$ & $34(40)$ & $2(50)$ & $7(47)$ & $17(47)$ & 0.861 \\
\hline Score throat & $55(40)$ & 31 (37) & $1(25)$ & $6(40)$ & $17(47)$ & 0.719 \\
\hline Nausea or vomiting & $30(22)$ & $16(19)$ & $1(25)$ & $6(40)$ & $7(19)$ & 0.294 \\
\hline Clumsiness & $20(14)$ & $13(15)$ & 0 & $3(20)$ & $4(11)$ & 0.801 \\
\hline Memory loss & $19(14)$ & $12(14)$ & 0 & $2(13)$ & $5(14)$ & 1.000 \\
\hline Skin lesions & $5(4)$ & $3(4)$ & 0 & 0 & $2(6)$ & 0.827 \\
\hline \multicolumn{7}{|l|}{ Cardiac } \\
\hline Shortness of breath & $68(49)$ & $36(43)$ & $3(75)$ & $11(73)$ & $18(50)$ & $0.112^{\mathbb{T I}}$ \\
\hline Palpitations & $44(32)$ & $24(29)$ & $3(75)$ & $9(60)$ & $8(22)$ & $0.013^{\mathbb{T I}}$ \\
\hline Chest pain & $40(29)$ & $22(26)$ & $2(50)$ & $5(33)$ & $11(31)$ & 0.658 \\
\hline Dizziness & $4(3)$ & 0 & 0 & $3(20)$ & $1(3)$ & $0.003^{\square \pi}$ \\
\hline At least one cardiac symptom & $86(62)$ & $46(55)$ & $3(75)$ & $13(87)$ & $24(67)$ & $0.085^{\square \pi}$ \\
\hline COVID-19 confirmed pneumonia & $27(19)$ & $20(24)$ & $1(25)$ & $4(27)$ & $2(6)$ & $0.059^{* *}$ \\
\hline
\end{tabular}




\begin{tabular}{|c|c|c|c|c|c|c|}
\hline & \multirow{2}{*}{$\begin{array}{l}\text { All participants } \\
\text { (N=139) }\end{array}$} & \multicolumn{4}{|c|}{ Presence of pericardial and myocardial manifestations } & \multirow[t]{2}{*}{$p$ value } \\
\hline & & $\begin{array}{c}\text { No } \\
(\mathrm{N}=84)\end{array}$ & $\begin{array}{c}\text { Pericarditis } \\
(n=4)\end{array}$ & $\begin{array}{c}\text { Myopericarditis } \\
(\mathrm{N}=15)\end{array}$ & $\begin{array}{c}\text { Myocarditis } \\
(\mathrm{N}=36)\end{array}$ & \\
\hline \multicolumn{7}{|l|}{ Cardiovascular chronic drug therapy } \\
\hline ACE inhibitors or ARB & $8(6)$ & $6(7)$ & 0 & 0 & $2(6)$ & 0.896 \\
\hline Beta-blocker & $2(1)$ & $1(1)$ & 0 & $1(7)$ & 0 & 0.321 \\
\hline Statin & $17(12)$ & $16(19)$ & 0 & $1(7)$ & 0 & $0.013^{\square * *}$ \\
\hline Antiplatelet & $5(4)$ & $5(6)$ & 0 & 0 & 0 & 0.468 \\
\hline Anticoagulant & $4(3)$ & $2(2)$ & 0 & $1(7)$ & 1 (3) & 0.493 \\
\hline \multicolumn{7}{|l|}{ Treatment at SARS-CoV-2 infection } \\
\hline Required hospitalization & $23(16)$ & $19(23)$ & $1(25)$ & $2(13)$ & $1(3)$ & $0.025^{\square * *}$ \\
\hline Oxygen therapy & $15(11)$ & $13(15)$ & 0 & $1(7)$ & $1(3)$ & $0.185^{\square}$ \\
\hline Paracetamol & $124(89)$ & $76(90)$ & $4(100)$ & $11(73)$ & $33(92)$ & 0.247 \\
\hline Ibuprofen & $17(12)$ & $9(11)$ & 0 & $5(33)$ & $3(8)$ & $0.102^{\mathbb{I I}}$ \\
\hline Azithromycin & $57(41)$ & $36(43)$ & $2(50)$ & $7(47)$ & $12(33)$ & 0.709 \\
\hline Hydroxychloroquine & $33(24)$ & $25(30)$ & $1(25)$ & $4(27)$ & $3(8)$ & $0.055^{\square * *}$ \\
\hline Lopinavir-ritonavir & $17(12)$ & $14(17)$ & $1(25)$ & $1(7)$ & $1(3)$ & $0.083^{* *}$ \\
\hline Oral glucocorticoids & $9(6)$ & $4(5)$ & $1(25)$ & $2(13)$ & $2(6)$ & 0.171 \\
\hline High-dose intravenous glucocorticoids ${ }^{\S}$ & $15(11)$ & $12(14)$ & $1(25)$ & $1(7)$ & 1 (3) & 0.141 \\
\hline Interleukin-6 inhibitors (tocilizumab, siltuximab) & $18(13)$ & $14(17)$ & $1(25)$ & $2(13)$ & $1(3)$ & $0.094^{* *}$ \\
\hline Interleukin-1 inhibitor (anakinra) & $2(1)$ & $2(2)$ & 0 & 0 & 0 & 1.000 \\
\hline \multicolumn{7}{|l|}{ Additional drug therapy at examination } \\
\hline Inhaled glucocorticoids & $5(4)$ & $3(4)$ & 0 & 0 & $2(6)$ & 0.862 \\
\hline Oral glucocorticoids & $2(1)$ & $1(1)$ & 0 & $1(7)$ & 0 & 0.321 \\
\hline Low-molecular weight heparin & $4(3)$ & $3(4)$ & 0 & $1(7)$ & 0 & 0.366 \\
\hline
\end{tabular}

Data are $\mathrm{n}(\%)$ and median (range). ${ }^{*}$ Obesity was considered if body-mass index of 30 or more. ${ }^{\dagger}$ Alcohol use was considered an average of at least one drink a day. ${ }^{*}$ All participants with previous pulmonary disease referred asthma. ${ }^{\S}$ High-dose intravenous glucocorticoids was considered when at least a bolus of methylprednisolone of $250 \mathrm{mg}$ was administered. $\mathrm{P}$ value for comparison among the four participants groups. Additional $\mathrm{p}$ value comparisons: $\square$ p value $<0.05$ no (non-pericardial and myocardial manifestations) vs presence of pericardial and myocardial manifestations; " $p$ value $<0.05$ no (nonpericardial and myocardial manifestations) vs myopericarditis; ${ }^{* *}$ p value $<0.05$ no (non-pericardial and myocardial manifestations) vs myocarditis. 


\section{Table 2. Study measures at examination}

\begin{tabular}{|c|c|c|c|c|c|c|}
\hline & \multirow{2}{*}{$\begin{array}{l}\text { All participants } \\
\quad(\mathrm{N}=139)\end{array}$} & \multicolumn{4}{|c|}{ Presence of pericardial and myocardial manifestations } & \multirow[t]{2}{*}{ p value } \\
\hline & & $\begin{array}{c}\text { No } \\
(\mathrm{N}=84)\end{array}$ & $\begin{array}{c}\text { Pericarditis } \\
\quad(n=4)\end{array}$ & $\begin{array}{l}\text { Myopericarditis } \\
\quad(\mathrm{N}=15)\end{array}$ & $\begin{array}{l}\text { Myocarditis } \\
(\mathrm{N}=36)\end{array}$ & \\
\hline Time from symptoms onset to examination (weeks) & $10.4(9.3-11.0)^{*}$ & $10.4(9.0-11.1)$ & $9.0(6.9-13.3)$ & $10.4(9.9-10.9)$ & $10.3(9.3-11.1)$ & 0.841 \\
\hline \multicolumn{7}{|c|}{ Time from SARS-CoV-2 test to examination (weeks) } \\
\hline RT-PCR & $9.4(8.1-10.0)$ & $9.6(7.9-10.1)$ & $7.0(5.7-8.6)$ & $9.5(9.1-10.4)$ & $9.4(8.6-10.0)$ & 0.170 \\
\hline Anti-SARS-CoV-2-IgG antibodies ${ }^{\dagger}$ & $4.4(3.6-5.0)$ & $4.6(3.1-5.0)$ & 4.3 & 2.3 & $4.0(3.6-4.8)$ & 0.501 \\
\hline \multicolumn{7}{|l|}{ Vital signs at examination } \\
\hline \multicolumn{7}{|l|}{ Blood pressure $(\mathrm{mm} \mathrm{Hg})$} \\
\hline Systolic & $124(113-139)$ & $125(115-142)$ & $127(114-142)$ & $121(112-139)$ & $114(107-136)$ & $0.073^{* * \S \S}$ \\
\hline Diastolic & $76(70-83)$ & $77(71-85)$ & $77(75-82)$ & $77(71-82)$ & $72(64-78)$ & $0.062^{* * \$ 8}$ \\
\hline Heart rate (bpm) & $70(63-80)$ & $70(63-82)$ & $68(64-88)$ & $70(57-73)$ & $72(63-80)$ & 0.816 \\
\hline Oxygen saturation $<95 \%$ & $10(7)$ & $9(11)$ & $1(25)$ & 0 & 0 & 0.043 \\
\hline \multicolumn{7}{|l|}{ Physical examination } \\
\hline Pericardial rub & 0 & 0 & 0 & 0 & 0 & 1.000 \\
\hline Heart murmur & $3(2)$ & $3(4)$ & 0 & 0 & 0 & 0.713 \\
\hline Third and fourth heart sound & 0 & 0 & 0 & 0 & 0 & 1.000 \\
\hline Pulmonary crackles & $5(4)$ & $4(5)$ & 0 & $1(7)$ & 0 & 0.391 \\
\hline \multicolumn{7}{|l|}{ Symptoms at examination } \\
\hline No symptoms & $48(34)$ & $33(39)$ & 0 & $3(20)$ & $12(33)$ & 0.274 \\
\hline \multicolumn{7}{|l|}{ General } \\
\hline Fatigue & $37(27)$ & $23(27)$ & $1(25)$ & $4(27)$ & $9(25)$ & 0.982 \\
\hline Anosmia & $12(9)$ & $5(6)$ & $1(25)$ & $1(7)$ & $5(14)$ & 0.188 \\
\hline Ageusia & $7(5)$ & $4(5)$ & $1(25)$ & 0 & $2(6)$ & 0.307 \\
\hline Headache & $7(5)$ & $4(5)$ & 0 & $2(13)$ & $1(3)$ & 0.455 \\
\hline Sore throat & $7(5)$ & $3(4)$ & 0 & $1(7)$ & $3(8)$ & 0.515 \\
\hline
\end{tabular}


Pericarditis and myocarditis long after SARS-CoV-2 infection: a cross-sectional descriptive study in health-care workers

Eiros et al. 20

\begin{tabular}{|c|c|c|c|c|c|c|}
\hline & \multirow{2}{*}{$\begin{array}{l}\text { All participants } \\
(\mathrm{N}=139)\end{array}$} & \multicolumn{4}{|c|}{ Presence of pericardial and myocardial manifestations } & \multirow[t]{2}{*}{$p$ value } \\
\hline & & $\begin{array}{c}\mathrm{No} \\
(\mathrm{N}=84)\end{array}$ & $\begin{array}{c}\text { Pericarditis } \\
\quad(n=4)\end{array}$ & $\begin{array}{l}\text { Myopericarditis } \\
(\mathrm{N}=15)\end{array}$ & $\begin{array}{c}\text { Myocarditis } \\
(\mathrm{N}=36)\end{array}$ & \\
\hline Abdominal pain & $6(4)$ & $3(4)$ & 0 & $1(7)$ & $2(6)$ & 0.625 \\
\hline Memory loss & $4(3)$ & $2(2)$ & 0 & 0 & $2(6)$ & 0.770 \\
\hline Join pain & $3(2)$ & $1(1)$ & 0 & $2(13)$ & 0 & 0.071 \\
\hline Piloerection & $2(1)$ & $1(1)$ & $1(25)$ & 0 & 0 & 0.068 \\
\hline \multicolumn{7}{|l|}{ Cardiac } \\
\hline Dyspnoea or shortness of breath & $36(26)$ & $20(24)$ & $2(50)$ & $7(47)$ & $7(19)$ & 0.115 \\
\hline Chest pain & $27(19)$ & $8(9)$ & $3(75)$ & $11(73)$ & $5(14)$ & $<0.001^{* *+\dagger}+t_{0}$ \\
\hline Pericarditis like & $18(13)$ & $3(4)$ & $3(75)$ & $11(73)$ & $1(3)$ & $<0.001^{* *+\dagger}+f_{+}$ \\
\hline Palpitations & $20(14)$ & $10(12)$ & $2(50)$ & $3(20)$ & $5(14)$ & 0.163 \\
\hline Dizziness & $8(6)$ & $2(2)$ & $1(25)$ & $2(13)$ & $3(8)$ & 0.040 \\
\hline At least one cardiac symptom & $58(42)$ & $28(33)$ & $4(100)$ & $11(73)$ & $15(42)$ & $0.002^{* *+\gamma \dagger}$ \\
\hline \multicolumn{7}{|l|}{ Electrocardiographic measures } \\
\hline Sinusal rhythm & $139(100)$ & $84(100)$ & $4(100)$ & $15(100)$ & $36(100)$ & 1.000 \\
\hline Sinus tachycardia over 100 beats per minute & $2(1)$ & $1(1)$ & 0 & 0 & $1(3)$ & 0.637 \\
\hline Sinus bradycardia under 50 beats per minute & $5(4)$ & $3(4)$ & 0 & 0 & $2(6)$ & 0.827 \\
\hline Extrasystole & $2(1)$ & $2(2)$ & 0 & 0 & 0 & 1.000 \\
\hline AV block or bundle branch block & $9(6)$ & $7(8)$ & 0 & 0 & $2(6)$ & 0.755 \\
\hline Intraventricular conduction delay & $15(11)$ & $9(11)$ & 0 & $1(7)$ & $5(14)$ & 0.903 \\
\hline ST-segment depression or T-wave inversion & $23(16)$ & $16(19)$ & $1(25)$ & $1(7)$ & $5(14)$ & 0.547 \\
\hline New Q waves & 0 & 0 & 0 & 0 & 0 & 1.000 \\
\hline Long-QT interval ${ }^{\ddagger}$ & $5(4)$ & $4(5)$ & 0 & $1(7)$ & 0 & 0.391 \\
\hline Low voltages & $5(4)$ & $1(1)$ & 0 & $2(13)$ & $2(6)$ & 0.069 \\
\hline Early repolarization & $8(6)$ & $7(8)$ & 0 & 0 & $1(3)$ & 0.576 \\
\hline \multicolumn{7}{|l|}{ Pericarditis like changes } \\
\hline Widespread ST elevation & $13(9)$ & $7(8)$ & 0 & $5(33)$ & $1(3)$ & $0.017^{+}$ \\
\hline PR depression & $33(24)$ & $17(20)$ & $2(50)$ & $8(53)$ & $6(17)$ & $0.016^{\dagger}$ \\
\hline
\end{tabular}




\begin{tabular}{|c|c|c|c|c|c|c|}
\hline & \multirow{2}{*}{$\begin{array}{l}\text { All participants } \\
\qquad(\mathrm{N}=139)\end{array}$} & \multicolumn{4}{|c|}{ Presence of pericardial and myocardial manifestations } & \multirow[t]{2}{*}{$p$ value } \\
\hline & & $\begin{array}{c}\text { No } \\
(\mathrm{N}=84)\end{array}$ & $\begin{array}{c}\text { Pericarditis } \\
(n=4)\end{array}$ & $\begin{array}{c}\text { Myopericarditis } \\
(\mathrm{N}=15)\end{array}$ & $\begin{array}{c}\text { Myocarditis } \\
(\mathrm{N}=36)\end{array}$ & \\
\hline \multicolumn{7}{|l|}{ Laboratory measures } \\
\hline Glomerular filtration rate $<60 \mathrm{ml} / \mathrm{min} \times 1.73 \mathrm{~m}^{2}$ & $2(1)$ & 0 & $1(25)$ & 0 & $1(3)$ & 0.033 \\
\hline High-sensitivity troponin $\mathrm{T}>14 \mathrm{pg} / \mathrm{ml}^{\S}$ & $1(1)$ & 0 & 0 & 0 & $1(3)$ & 0.396 \\
\hline NT-pro-BNP $\geq 125 \mathrm{pg} / \mathrm{ml}$ & $11(8)$ & $5(6)$ & 0 & $2(13)$ & $4(11)$ & 0.541 \\
\hline C-reactive protein $>3 \mathrm{mg} / \mathrm{dl}$ & $10(7)$ & $5(6)$ & $1(25)$ & 0 & $4(11)$ & 0.222 \\
\hline \multicolumn{7}{|l|}{ CMR imaging measures } \\
\hline Increase of myocardial T2-relaxation time & $6(4)$ & $1(1)$ & 0 & $1(7)$ & $4(11)$ & $0.066^{* * \S \S}$ \\
\hline T2-weighted hyperintensity & $6(4)$ & 0 & 0 & $1(7)$ & $5(14)$ & $0.006^{* * \S \S}$ \\
\hline Increase of native myocardial T1-relaxation time & $58(42)$ & $24(29)$ & 0 & $7(47)$ & $27(75)$ & $<0.001^{* * \S \S}$ \\
\hline Increase of T1-extracellular volume & $52(37)$ & $17(20)$ & 0 & $9(60)$ & $26(72)$ & $<0.001^{* *+\hbar s}$ \\
\hline T1-late gadolinium enhancement & $10(7)$ & $2(2)$ & 0 & $4(27)$ & $4(11)$ & $0.008^{* *+\hbar}$ \\
\hline Pericardial effusion ${ }^{\square}$ & $42(30)$ & $4(5)$ & $3(75)$ & $15(100)$ & $20(57)$ & $<0.001^{* *+\hbar s \&}$ \\
\hline Pericardial thickening ${ }^{\mathbb{I I}}$ & $1(1)$ & 0 & 0 & $1(7)$ & 0 & 0.137 \\
\hline Systolic left ventricular wall motion abnormalities & $7(5)$ & $3(4)$ & 0 & 0 & $4(11)$ & 0.340 \\
\hline
\end{tabular}

Data are $\mathrm{n}(\%)$ and median (IQR). ${ }^{*}$ Data regarding time from symptoms onset to examination was not possible to calculate for 2 patients who were totally asymptomatic. ${ }^{\dagger}$ Only one case with pericarditis and another case with myopericarditis in participants diagnosed of past SARS-CoV-2 infection through serology. ${ }^{+}$Long-QT interval was defined as a rate-corrected (Bazett) QT interval exceeding 450 milliseconds in males and 460 milliseconds in females. ${ }^{8}$ The $99^{\text {th }}$ percentile of troponin values for our laboratory is $14 \mathrm{pg} / \mathrm{ml}$. Pericardial effusion greater than $3 \mathrm{~mm}$. ${ }^{\mathbb{I}}$ Pericardial thickness of $3 \mathrm{~mm}$ on T1-weighted spin-echo CMR. P value for comparison among the four participants groups. Additional $\mathrm{p}$ value comparisons: ${ }^{* *} \mathrm{p}$ value $<0.05$ no (non-pericardial and myocardial manifestations) vs presence of pericardial and myocardial manifestations; $\dagger p$ value $<0.05$ no (non-pericardial and myocardial manifestations) vs pericarditis; ${ }^{\stackrel{*}{*}} \mathrm{p}$ value $<0.05$ no (non-pericardial and myocardial manifestations) vs myopericarditis; ${ }^{\$ \S}$ p value $<0.05$ no (non-pericardial and myocardial manifestations) vs myocarditis. 
Table 3. Distribution of subsets of myeloid immune cells in blood

\begin{tabular}{|c|c|c|c|c|c|c|c|c|c|}
\hline & \multirow{2}{*}{$\begin{array}{l}\text { Healthy donors } \\
\qquad(\mathrm{N}=463)\end{array}$} & \multirow{2}{*}{$\begin{array}{l}\text { All participants } \\
\text { ( } N=139)\end{array}$} & \multirow[t]{2}{*}{ p value } & \multicolumn{4}{|c|}{ Presence of pericardial and myocardial manifestations } & \multirow[t]{2}{*}{$p$ value } & \\
\hline & & & & $\begin{array}{c}\text { No } \\
(\mathrm{N}=84)\end{array}$ & $\begin{array}{c}\text { Pericarditis } \\
(n=4)\end{array}$ & $\begin{array}{l}\text { Myopericarditis } \\
(\mathrm{N}=15)\end{array}$ & $\begin{array}{c}\text { Myocarditis } \\
(\mathrm{N}=36)\end{array}$ & & \\
\hline Neutrophils & 3723 (2969-4613) & $3430(2633-4225)$ & $0.004^{* \S}$ & $3413(2647-4122)$ & $2767(2386-5975)$ & $3734(3121-4249)$ & $3290(2318-4407)$ & 0.650 & \\
\hline$\%$ cases $\downarrow 5^{\text {th }} \mathrm{p} / \uparrow 95^{\text {th }} \mathrm{p}$ & - & $18(13) / 5(5)$ & $<0.001 / 0.001$ & $9(11) / 5(6)$ & $0 / 0$ & $1(7) / 0$ & $8(22) / 2(6)$ & $0.299 / 0.794$ & \\
\hline MDSC-like Neutrophils & $5(2-12)$ & $2(1-5)$ & $<0.001^{* \neq \S}$ & $3(1-8)$ & $2(0.7-28)$ & $2(0.7-3)$ & $2(1-4)$ & 0.270 & $\overline{\bar{\omega}}$ \\
\hline Immature $\mathrm{CD} 16{ }^{\circ} \mathrm{CD} 62 \mathrm{~L}^{-}$ & $5(2-9)$ & $2(0.8-4)$ & $<0.001^{\ddagger \S}$ & $2(0.9-6)$ & $2(0.6-23)$ & $0.9(0.6-2)$ & $2(0.8-3)$ & 0.280 & కై \\
\hline Immature $\mathrm{CD} 16 \mathrm{CD} 62 \mathrm{~L}^{+}$ & $0.5(0.2-1)$ & $0.5(0.3-1)$ & 0.920 & $0.5(0.3-1)$ & $0.5(0.2-5)$ & $0.3(0.1-0.9)$ & $0.4(0.2-0.8)$ & 0.270 & 2 \\
\hline Eosinophils & $157(101-249)$ & $74(47-149)$ & $<0.001^{* \dagger+\S}$ & $82(50-120)$ & $34(31-164)$ & $61(46-126)$ & $105(50-179)$ & 0.340 & . \\
\hline$\%$ cases $\downarrow 5^{\text {th }} \mathrm{p} / \uparrow 95^{\text {th }} \mathrm{p}$ & - & $38(27) / 1(0.7)$ & $<0.001 / 0.200$ & $21(25) / 1(1)$ & $3(75) / 0$ & $4(27) / 0$ & $10(28) / 0$ & $0.840 / 0.883$ & $\frac{\bar{v}}{0,}$ \\
\hline Basophils & $38(21-52)$ & $47(35-62)$ & $0.013^{* d}$ & $48(37-52)$ & $34(13-55)$ & $34(29-56)$ & $51(38-64)$ & 0.210 & $\stackrel{10}{5}$ \\
\hline$\%$ cases $\downarrow 5^{\text {th }} \mathrm{p} / \uparrow 95^{\text {th }} \mathrm{p}$ & - & $4(2) / 5(3)$ & $0.001 / 0.001$ & $1(1) / 3(3)$ & $1(25) / 1(25)$ & $1(6) / 1(6)$ & $1(2) / 0$ & $0.842 / 0.672$ & $\stackrel{\circ}{\mathbb{Q}}$ \\
\hline Monocytes & $317(245-433)$ & $405(328-523)$ & $<0.001^{*}$ & $421(346-528)$ & $376(351-785)$ & $385(297-442)$ & $368(292-557)$ & $0.330^{\square \llbracket}$ & $\stackrel{\infty}{2}$ \\
\hline$\%$ cases $\downarrow 5^{\text {th }} p / \uparrow 95^{\text {th }} p$ & - & $7(5) / 6(4)$ & $<0.001 /<0.001$ & $4(5) / 3(4)$ & $0 / 1(25)$ & $3(20) / 0$ & $0 / 2(6)$ & $0.185 / 0.650$ & $\begin{array}{l}0 \\
\text { W } \\
\text { d }\end{array}$ \\
\hline Classical monocytes & $290(240-383)$ & $386(308-492)$ & $<0.001^{*}$ & $423(356-500)$ & $382(319-669)$ & $376(308-518)$ & $341(272-409)$ & $0.059^{\square \mathbb{I}}$ & $\sum_{2}^{r}$ \\
\hline $\mathrm{CD} 2 \mathrm{~L}^{+} \mathrm{Fc} \mathrm{e} \mathrm{RI}^{+}$ & $46(7-70)$ & $12(3-56)$ & $0.038^{\ddagger \S}$ & $18(5-73)$ & $4(1-15)$ & $2(0.7-6)$ & $11(3-34)$ & $0.020^{\mathbb{I}}$ & \\
\hline $\mathrm{CD} 2 \mathrm{~L}^{+} \mathrm{Fc}$ ?RI $\mathrm{R}^{-}$ & $205(132-269)$ & $230(156-304)$ & $0.170^{*}$ & $245(160-330)$ & $263(248-580)$ & $189(54-293)$ & $196(156-252)$ & $0.057^{\mathbb{I I}}$ & $P$ \\
\hline $\mathrm{CD} 6 \mathrm{~L}^{-} \mathrm{Fc}$ 回 $\mathrm{RI}^{+}$ & $7(2-33)$ & $2(0.3-7)$ & $0.001^{* \ddagger \S}$ & $2(0.3-9)$ & $0.4(0.1-4)$ & $0.5(0.1-7)$ & $2(0.3-7)$ & 0.740 & $\stackrel{0}{5}$ \\
\hline $\mathrm{CD}^{2} 2 \mathrm{~L}^{-} \mathrm{Fc}$ ? $\left.\mathrm{RI}\right|^{-}$ & $101(52-258)$ & $39(18-77)$ & $<0.001^{* \uparrow \S}$ & $35(16-77)$ & $23(13-36)$ & $49(19-100)$ & $47(28-72)$ & 0.560 & J \\
\hline Intermediate monocytes & $20(15-29)$ & $14(9-20)$ & $0.001^{* * \S}$ & $15(10-21)$ & $9(4-14)$ & $13(5-17)$ & $13(9-18)$ & 0.150 & $\begin{array}{l}\stackrel{0}{\overrightarrow{0}} \\
\stackrel{\overrightarrow{0}}{\underline{*}}\end{array}$ \\
\hline Non-classical monocytes & $49(36-62)$ & $42(27-63)$ & 0.170 & $43(27-63)$ & $36(13-51)$ & $45(11-73)$ & $39(27-58)$ & 0.730 & $\stackrel{0}{\varrho}$ \\
\hline Dendritic cells & $29(20-35)$ & $28(20-35)$ & 0.620 & $29(21-35)$ & $28(22-31)$ & $29(18-36)$ & $23(17-35)$ & 0.420 & $\stackrel{\Phi}{工}$ \\
\hline$\%$ cases $\downarrow 5^{\text {th }} p / \uparrow 95^{\text {th }} p$ & - & $14(10) / 5(3)$ & $<0.001 / 0.001$ & $7(8) / 5(5)$ & $1(25) / 0$ & $6(40) / 0$ & $0 / 0$ & $0.556 / 0.343$ & $\begin{array}{l}\mathscr{D}_{0} \\
\text { D }\end{array}$ \\
\hline Myeloid dendritic cells & $18(14-26)$ & $19(14-26)$ & 0.600 & $19(14-25)$ & $20(14-26)$ & $21(15-29)$ & $17(13-28)$ & 0.800 & \\
\hline $\mathrm{CD} 1 \mathrm{c}^{+} \mathrm{m}$ dendritic cells & $17(14-25)$ & $19(14-25)$ & 0.570 & $19(14-25)$ & $19(13-26)$ & $20(14-27)$ & $16(13-24)$ & 0.790 & \\
\hline $\mathrm{CD} 141^{+} \mathrm{m}$ dend ritic cells & $1(0.6-1)$ & $0.9(0.6-1)$ & 0.640 & $0.9(0.6-1)$ & $0.6(0.5-0.7)$ & $0.8(0.7-1)$ & $0.6(0.5-1)$ & 0.054 & \\
\hline Plasmacytoid dendritic cells & $8(6-11)$ & $6(4-9)$ & $0.020^{\S}$ & $7(5-10)$ & $7(2-12)$ & $6(4-8)$ & $5(4-8)$ & 0.063 & \\
\hline $\mathrm{Axl}^{+}$dendritic cells & $0.3(0.2-0.4)$ & $0.3(0.2-0.5)$ & 0.560 & $0.3(0.2-0.5)$ & $0.3(0.2-0.4)$ & $0.3(0.2-0.5)$ & $0.2(0.1-0.3)$ & 0.330 & \\
\hline
\end{tabular}


Data are median (IQR) of cells $/ \mu \mathrm{L}$ of blood or $\mathrm{n}(\%)$ of cases lower than 5 th percentile $\left(\downarrow 5^{\text {th }} \mathrm{p}\right)$ and higher than 95 th percentile $\left(\uparrow 95^{\text {th }} \mathrm{p}\right)$ for each cell subset in agematched healthy donors. Left $\mathrm{p}$ value for comparisons between healthy donors vs all participants. Right $\mathrm{p}$ value for comparison among the four participants groups. Additional $\mathrm{p}$ value comparisons: ${ }^{\mathrm{p}} \mathrm{p}$ value $<0.05$ healthy donors vs no (non-pericardial and myocardial manifestations); ${ }^{\dagger} \mathrm{p}$ value $<0.05$ healthy donors vs pericarditis; ${ }^{*} \mathrm{p}$ value $<0.05$ healthy donors vs myopericarditis; ${ }^{\$} \mathrm{p}$ value $<0.05$ healthy donors vs myocarditis; ${ }^{\circ}$ value $<0.05$ no (non-pericardial and myocardial manifestations) vs myocarditis. " $\mathrm{p}$ value $<0.05$ no (non-pericardial and myocardial manifestations) vs myopericarditis plus myocarditis. MDSC $=$ myeloid-derived suppressor cells; $\mathrm{m}=$ myeloid. 
Table 4. Distribution of the major subsets of lymphoid cells in blood

\begin{tabular}{|c|c|c|c|c|c|c|c|c|}
\hline & \multirow{2}{*}{$\begin{array}{l}\text { Healthy donors } \\
\quad(\mathrm{N}=463)\end{array}$} & \multirow{2}{*}{$\begin{array}{l}\text { All participants } \\
(N=139)\end{array}$} & \multirow[t]{2}{*}{$p$ value } & \multicolumn{4}{|c|}{ Presence of pericardial and myocardial manifestations } & \multirow[t]{2}{*}{$p$ value } \\
\hline & & & & $\begin{array}{c}\text { No } \\
(\mathrm{N}=84)\end{array}$ & $\begin{array}{l}\text { Pericarditis } \\
(n=4)\end{array}$ & $\begin{array}{l}\text { Myopericarditis } \\
(\mathrm{N}=15)\end{array}$ & $\begin{array}{c}\text { Myocarditis } \\
(\mathrm{N}=36)\end{array}$ & \\
\hline Lymphocytes & 1675 (1332-2223) & $2221(1717-2563)$ & $<0.001^{* 8}$ & $2294(1847-2779)$ & $2392(1729-3876)$ & $1660(1379-2070)$ & $2105(1717-2538)$ & $0.006^{\mathbb{I I \dagger \dagger}}$ \\
\hline$\%$ cases $\downarrow 5^{\text {th }} \mathrm{p} / \uparrow 95^{\text {th }} \mathrm{p}^{*}$ & - & $3(2) / 8(6)$ & $0.012 /<0.001$ & $1(1) / 6(7)$ & $0 / 1(25)$ & $2(13) / 0$ & $0 / 1(3)$ & $0.180 / 0.209$ \\
\hline T cells & $1246(943-1642)$ & $1652(1348-1985)$ & $<0.001^{* 8}$ & $1748(1423-2003)$ & $1831(1280-2757)$ & $1350(1186-1480)$ & $1664(1350-2019)$ & $0.011^{1 * * *}$ \\
\hline$\%$ cases $\downarrow 5^{\text {th }} p / \uparrow 95^{\text {th }} \mathrm{p}^{*}$ & - & $1(1) / 10(7)$ & $0.200 /<0.001$ & $0 / 8(10)$ & $0 / 1(25)$ & $1(7) / 0$ & $0 / 1(3)$ & $0.379 / 0.187$ \\
\hline $\mathrm{CD} 4+\mathrm{T}$ cells & 716 (567-961) & $1017(791-1213)$ & $<0.001^{* 8}$ & $1036(86-1271)$ & $950(846-1517)$ & $841(718-902)$ & $1049(729-1334)$ & 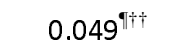 \\
\hline$\%$ cases $\downarrow 5^{\text {th }} p / \uparrow 95^{\text {th }} p^{*}$ & - & $1(1) / 14(10)$ & $0.200 /<0.001$ & $0 / 8(10)$ & $0 / 1(25)$ & 1 (7) / 0 & $0 / 5(14)$ & $0.379 / 0.175$ \\
\hline $\mathrm{CD} 8+\mathrm{T}$ cells & $407(291-590)$ & $507(388-696)$ & $<0.001^{* \S}$ & $547(399-762)$ & $684(323-1090)$ & $403(337-548)$ & $523(393-631)$ & $0.089^{\mathrm{II}}$ \\
\hline$\%$ cases $\downarrow 5^{\text {th }} p / \uparrow 95^{\text {th }} p^{*}$ & - & $0 / 9(6)$ & $-/<0.001$ & $0 / 7(8)$ & $0 / 1(25)$ & $0 / 0$ & $0 / 1(3)$ & $-/ 0.204$ \\
\hline $\mathrm{CD} 4{ }^{-C D} 8^{-10} T \alpha \beta$ cells & $46(28-79)$ & $78(48-130)$ & $<0.001^{*+\ddagger 8}$ & $90(52-133)$ & $137(76-247)$ & $71(64-79)$ & $67(37-115)$ & $0.056^{* * \S \S}$ \\
\hline$\%$ cases $\downarrow 5^{\text {th }} p / \uparrow 95^{\text {th }} p^{*}$ & - & $5(4) / 24(17)$ & $0.003 /<0.001$ & $4(5) / 16(19)$ & $0 / 1(25)$ & $1(7) / 2(13)$ & $0 / 5(14)$ & $0.526 / 0.845$ \\
\hline 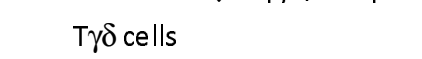 & $56(33-107)$ & $59(31-93)$ & 0.580 & $59(33-93)$ & $113(67-194)$ & $49(36-58)$ & $46(21-85)$ & 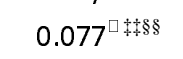 \\
\hline$\%$ cases $\downarrow 5^{\text {th }} p / \uparrow 95^{\text {th }} p^{*}$ & - & $2(1) / 8(6)$ & $0.053 /<0.001$ & $2(2) / 6(7)$ & $0 / 1(25)$ & $0 / 0$ & $6(17) / 0$ & $0.013 / 0.078$ \\
\hline NK cells & $260(162-372)$ & $213(137-321)$ & $0.007^{\ddagger \S}$ & $240(143-337)$ & $195(142-341)$ & $120(82-289)$ & $177(137-256)$ & $0.084^{\mathbb{I * *}}$ \\
\hline$\%$ cases $\downarrow 5^{\text {th }} \mathrm{p} / \uparrow 95^{\text {th }} \mathrm{p}^{*}$ & - & $9(6) / 6(4)$ & $<0.001 / 0.001$ & $4(5) / 4(5)$ & $0 / 0$ & $3(20) / 0$ & $2(6) / 2(6)$ & $0.153 / 0.794$ \\
\hline B cells & $154(108-228)$ & $208(158-297)$ & $<0.001^{*+\xi}$ & $233(175-327)$ & $303(216-930)$ & $167(132-188)$ & $202(146-245)$ & $0.011^{\mathbb{I}^{* *} \S \S}$ \\
\hline$\%$ cases $\downarrow 5^{\text {th }} \mathrm{p} / \uparrow 95^{\text {th }} \mathrm{p}^{*}$ & - & $2(1) / 16(12)$ & $0.053 /<0.001$ & $1(1) / 10(12)$ & $0 / 1(25)$ & 1()$/ 1(7)$ & $0 / 4(11)$ & $0.319 / 0.782$ \\
\hline Plasma cells & $2(0.8-3)$ & $0.8(0.3-2)$ & $<0.001^{* * 8}$ & $0.8(0.4-2)$ & $1(0.5-3)$ & $0.4(0.2-0.8)$ & $1(0.3-2)$ & $0.140^{\mathrm{II}}$ \\
\hline$\%$ cases $\downarrow 5^{\text {th }} p / \uparrow 95^{\text {th }} p^{*}$ & - & $11(8) / 1(1)$ & $<0.001 / 0.200$ & $6(7) / 1$ (1) & $0 / 0$ & $2(13) / 0$ & $3(8) / 0$ & $0.795 / 0.883$ \\
\hline
\end{tabular}

Data are median (IQR) of cells $/ \mu \mathrm{L}$ of blood or $\mathrm{n}(\%)$ of cases lower than 5 th percentile $\left(\downarrow 5^{\text {th }} \mathrm{p}\right)$ and higher than 95 th percentile $\left(\uparrow 95^{\text {th }} \mathrm{p}\right)$ for each cell subset in agematched healthy donors. Left $\mathrm{p}$ value for comparisons between healthy donors vs all participants. Right $\mathrm{p}$ value for comparison among the four participants groups. Additional $\mathrm{p}$ value comparisons: ${ }^{*} \mathrm{p}$ value $<0.05$ healthy donors vs no (non-pericardial and myocardial manifestations); ${ }^{\dagger} \mathrm{p}$ value $<0.05$ healthy donors vs pericarditis; ${ }^{\star} \mathrm{p}$ value $<0.05$ healthy donors vs myopericarditis; ${ }^{\S} \mathrm{p}$ value $<0.05$ healthy donors vs myocarditis; ${ }^{\square} \mathrm{p}$ value $<0.05$ no (non-pericardial and myocardial manifestations) vs pericarditis. "p value $<0.05$ no (non-pericardial and myocardial manifestations) vs myopericarditis; ${ }^{* *} \mathrm{p}$ value $<0.05$ no (non-pericardial and myocardial manifestations) vs myopericarditis plus myocarditis; ${ }^{\dagger \dagger} \mathrm{p}$ value $<0.05$ pericarditis vs myopericarditis; ${ }^{\dagger p}$ p value $<0.05$ pericarditis vs myocarditis; ${ }^{\S \S} \mathrm{p}$ value $<0.05$ myopericarditis vs myocarditis. $\mathrm{NK}=$ natural killer. 
medRxiv preprint doi: https://doi.org/10.1101/2020.07.12.20151316; this version posted July 14, 2020. The copyright holder for this preprint (which was not certified by peer review) is the author/funder, who has granted medRxiv a license to display the preprint in perpetuity. It is made available under a CC-BY-NC-ND 4.0 International license .

\section{Funding}

This study was supported by CIBERCV (CB16/11/00374), CIBERONC

(CB16/12/00400) and the COV20/00386 grant from the Instituto de Salud Carlos III and FEDER, Ministerio de Ciencia e Innovación, Madrid, Spain. 


\section{Disclosures}

A.Orfao J.Almeida, M.Perez-Andres, V.Botafogo, D.Damasceno report being one of the inventors on the EuroFlow-owned European patent 119646NL00 registered in November 2019 ("Means and methods for multiparameter flow cytometry based leukocyte subsetting") and A.Orfao and J.Almeida are also authors of the PCT patent WO 2010/140885A1 ("Methods, reagents and kits for flow cytometric immunophenotyping"). The Infinicyt software is based on intellectual property (IP) of the University of Salamanca in Spain. All above mentioned intellectual property and related patents are licensed to Cytognos (Salamanca, ES) and Becton/Dickinson Biosciences (San José, California), which companies pay royalties to the EuroFlow Consortium. These royalties are exclusively used for continuation of the EuroFlow collaboration and sustainability of the EuroFlow consortium. There are no other conflicts of interest related to this study or for the rest of authors.

\section{Acknowledgments}

We thank all health-care workers participating in this study, to all the personnel of the University Hospital of Salamanca for their extraordinary work in their fight against this pandemic, and all other participating institutions. We also would like to thank Prof Dr Jacques JM van Dongen and both his group (Leiden University Medical Center) and the EuroFlow Consortia for their contribution in the design, construction and validation of the EuroFlow LST and IMM tubes used herein. 
medRxiv preprint doi: https://doi.org/10.1101/2020.07.12.20151316; this version posted July 14, 2020. The copyright holder for this preprint

(which was not certified by peer review) is the author/funder, who has granted medRxiv a license to display the preprint in perpetuity.

It is made available under a CC-BY-NC-ND 4.0 International license .

Pericarditis and myocarditis long after SARS-CoV-2 infection: a cross-sectional

descriptive study in health-care workers

Eiros et al. 27

\section{Authors contribution}

RE, MBP, JA, JLBG, AO, PLS conceived and designed the study; RE, MB-P, AO, PLS contributed to the literature research; RE, SM, IT contributed with clinical evaluation of the participants; SM, CS-P, IT, EDP, LMA contributed with clinical data collection; MBP, AMG contributed to data analysis (cardiac magnetic resonance); EV, DGC contributed to data analysis (ECG); APP, ATV, OPE, BFH performed immunophenotypic and serology experiments and collected data; JA, BFH, GOA, QL, RF, AO contributed to data analysis and interpretation (Immunophenotypic and serology); RE, MBP, AMG, EV, AO, PLS, contributed to clinical data analysis and interpretation; MBP, JA, JLBG, AO, PLS contributed to writing of the report. 
220 health care workers identified by the Occupational Health Service of UHS in whom SARS-CoV-2 infection was confirmed with RT-PCR from 15 March to 25 April 2020

\section{0 deaths}

126 consecutively contacted to participate in the study

18 refused to participate

1 claustrophobia

1 pacemaker

94 never contacted

106 signed the informed consent and examinations performed from 25 May to June 12
229 health care workers identified by the Occupational Health Service of UHS in whom SARS-CoV-2 infection was confirmed with anti-SARS-CoV-2-IgG antibodies from 10 April to 22 May 2020

0 deaths

40 consecutively contacted to participate

in the study

3 refused to participate

1 gadobutrol allergy

189 never contacted

36 signed the informed consent and examinations performed from 25 May to June 12

1 excluded from analysis as CMR was not completed for claustrophobia

1 excluded from analysis as history of severe hypertrophic myocardiopathy

1 excluded for history of inherited immune deficiency

139 clinical evaluation

laboratory with troponin, NT-pro-BNP, C-reactive protein,

and cellular and humoral immune response assessments

electrocardiography

cardiac magnetic resonance imaging 


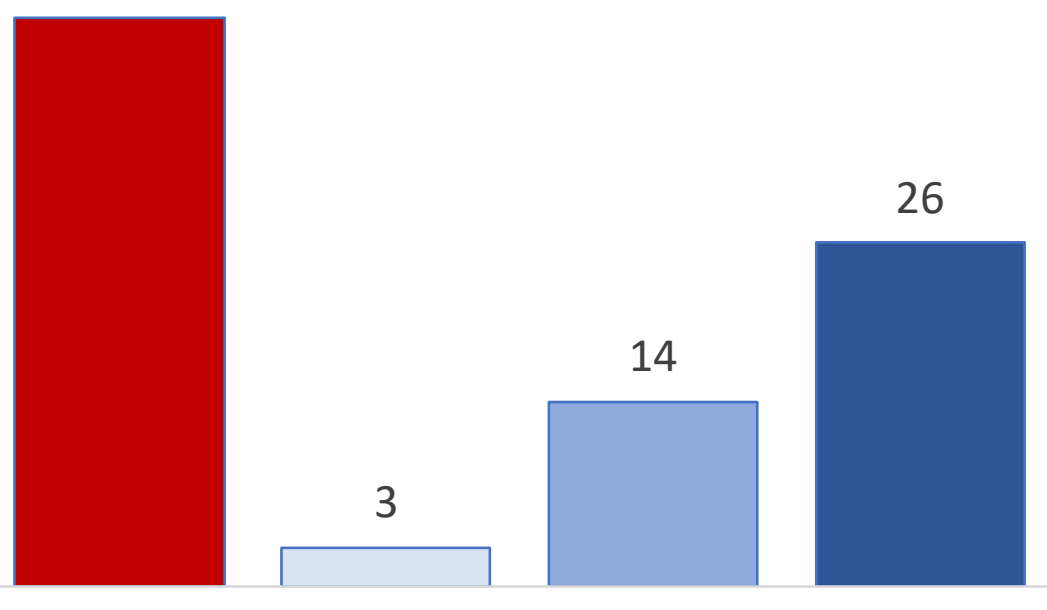

Diagnosis of SARS-2-CoV infection through positive RT-PCR

31

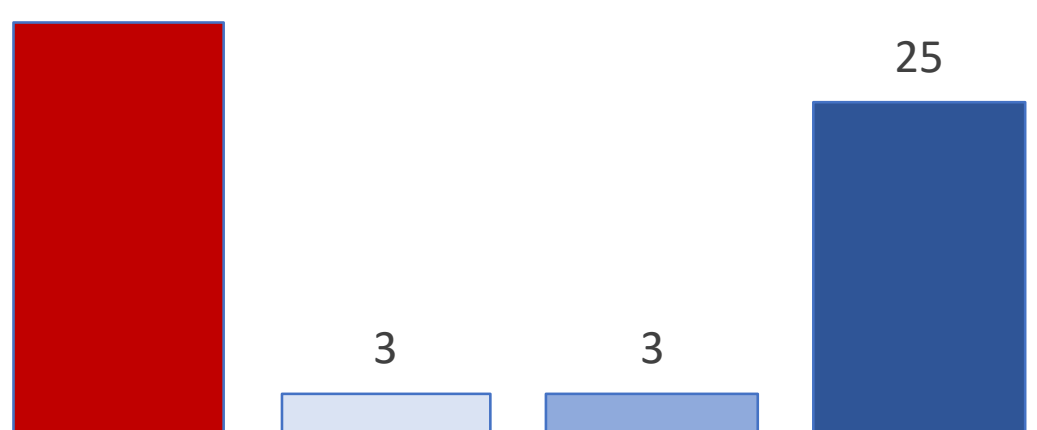

25 
